IZADP No. 2395

The Effects of Divorce Risk on the Labour Supply of Married Couples

Kerry L. Papps

October 2006 


\title{
The Effects of Divorce Risk on the Labour Supply of Married Couples
}

\author{
Kerry L. Papps \\ Cornell University \\ and IZA Bonn
}

\section{Discussion Paper No. 2395 \\ October 2006}

\author{
IZA \\ P.O. Box 7240 \\ 53072 Bonn \\ Germany \\ Phone: +49-228-3894-0 \\ Fax: +49-228-3894-180 \\ Email: iza@iza.org
}

\begin{abstract}
Any opinions expressed here are those of the author(s) and not those of the institute. Research disseminated by IZA may include views on policy, but the institute itself takes no institutional policy positions.
\end{abstract}

The Institute for the Study of Labor (IZA) in Bonn is a local and virtual international research center and a place of communication between science, politics and business. IZA is an independent nonprofit company supported by Deutsche Post World Net. The center is associated with the University of Bonn and offers a stimulating research environment through its research networks, research support, and visitors and doctoral programs. IZA engages in (i) original and internationally competitive research in all fields of labor economics, (ii) development of policy concepts, and (iii) dissemination of research results and concepts to the interested public.

IZA Discussion Papers often represent preliminary work and are circulated to encourage discussion. Citation of such a paper should account for its provisional character. A revised version may be available directly from the author. 


\section{ABSTRACT}

\section{The Effects of Divorce Risk on the Labour Supply of Married Couples}

This paper presents a model of lifetime utility maximisation in which expectations of future marital transitions play a role in the determination of work hours. Married people with spouses who earn more are predicted to devote additional time to the labour market when they are confronted with a high likelihood of divorce and vice versa. Similarly, work hours should be positively associated with marriage probability for those single people who expect to marry a higher earning spouse. These predictions are tested using data from the National Longitudinal Survey of Youth 1979. Marriage and divorce probabilities are calculated from Cox proportional hazard models and are included in regressions of annual hours. Married women are found to work more when they face a high probability of divorce. This relationship holds both over an individual's life-cycle and across people with different inherent risks of divorce. Similar results are found when a woman's happiness with her marriage is used as a proxy for divorce risk.

JEL Classification: J12, J22

Keywords: divorce, labour supply, hazard models

Corresponding author:

Kerry L. Papps

Department of Economics

Uris Hall

Cornell University

Ithaca, NY 14853

USA

E-mail: klp27@cornell.edu

\footnotetext{
* The author wishes to thank Fran Blau, Larry Kahn, John Abowd, Lynn Gottschalk, Liz Peters and Rainer Winkelmann for their helpful comments, as well as participants at the 2006 New Zealand Association of Economists conference and seminars at the University of Canterbury, Victoria University of Wellington and Cornell University.
} 
"A divorcée is a woman who got married so she didn't have to work, but now works so she doesn't have to get married.”

ANNA MAGNANI

\section{Introduction}

It is a commonly-held assumption that married men earn more than unmarried men because they are able to specialise in labour market work and, hence, acquire more human capital, while their wives perform the bulk of unpaid tasks within the household. In this case, the event of divorce should have important economic consequences for both husband and wife. Divorced men are likely to experience declining wages relative to men who remain married, as their accumulated human capital gradually depreciates. Women are likely to be forced to enter the labour market or increase their hours of work after divorce and be paid less than single women, who have more human capital. However, if women make labour supply decisions optimally, taking into account the probability of their marriage dissolving, then they may choose to devote more time to market work while still married, in order to boost their future earnings capacity in the event of divorce. Presumably, the higher the probability of divorce is, the more hours a married woman will want to work. This phenomenon should be observed both across groups with different divorce rates and over time, as couples assess the quality of their match and decide whether to continue their marriage.

Figure 1 displays the evolution of the labour force participation rate among married women in the United States over the past half-century, as well as the number of divorces per 1000 married women and the real hourly wage for employed married women. The labour force participation rate reached a plateau in the 1990s after four decades of steady growth. Meanwhile, the divorce rate rose sharply in the 1960s and 1970s, before declining somewhat. Wages grew in most periods, but most steeply in the 1990s.

Previous research has largely attributed the post-war increase in female participation in the United States labour market to growth in the real wage offered to women. However, estimates suggest that this can only explain around half of the total increase in female participation rates. Furthermore, Shapiro and Shaw (1983) noted that during the 1970s, labour force participation by married women continued to grow, despite a stagnant real wage, as seen in Figure 1. More recently, Blau and Kahn (2005) presented evidence 
Figure 1

Trends in labour force participation, divorce and wages among married women

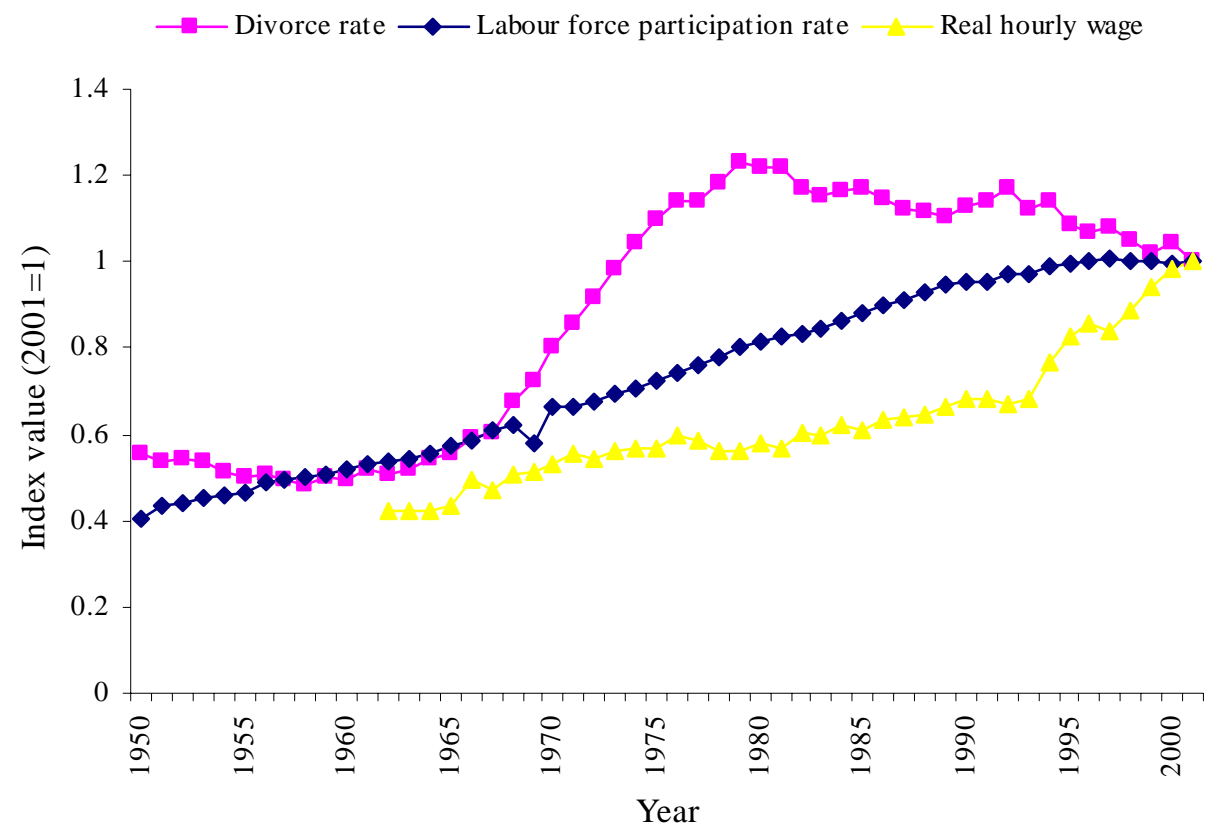

Sources: Divorce rate (divorces per married women aged 15 and over): Clarke (1995) and author's calculations, based on data from National Center for Health Statistics; labour force participation rate: United States Census Bureau (2003), based on Current Population Survey data; wage rate: author's calculations based on March Current Population Survey data.

that married women's labour supply function shifted significantly to the right in the 1980s, with little movement in the 1990s, and that the difference in this shift accounted for the more dramatic growth in female labour supply during the former decade. Given that divorce rates were increasing prior to the 1980s and fell leading into the 1990s, it is plausible that these puzzles may at least in part be explained by a reaction of women to changes in marital instability.

Apart from a strand of literature investigating the effect of divorce law reform, few previous studies have examined the effect that the threat of divorce has on the labour supply decisions of married couples and none of these has presented any theory that might explain this behaviour. As Lundberg and Pollak (1996) note, if "the analysis of marriage and divorce is awkward, the analysis of marital decisions in the shadow of divorce is even more so" (p. 143). Furthermore, most papers have used only crosssectional data or a few years of panel data and have thus been unable to examine whether human capital accumulation over the entire duration of a marriage is an important feature 
in the labour supply decisions of couples.

This paper represents the first attempt to model the effect both marriage and divorce probabilities have on labour supply and wages within a utility maximisation framework. I develop a theoretical model that is based on a setting in which men and women each maximise their own lifetime utility and married couples interact in a non-cooperative manner. Wages are determined by the number of hours a person has worked in the past. The probability of marriage is found to increase work hours for those unmarried people who expect to marry someone with a lower wage rate. This is more likely to be the case for men than women. Conversely, among married couples, an increase in the likelihood of divorce has a positive effect on labour supply for those who earn less per hour than their spouses: something that is likely for women but not men.

This model is then tested using data from the National Longitudinal Survey of Youth (NLSY) 1979 for the period 1979-2004. Cox proportional hazard models are used to generate estimated probabilities of marriage among single people and divorce among married people each period. The estimated marriage and divorce probabilities are then used as explanatory variables in labour supply regressions. For those in their first marriage, a 0.01 increase in the annual probability of divorce results in a wife working around 60 extra hours a year, consistent with theoretical predictions. Higher marriage probabilities are associated with increases in the hours worked by single men, but also among single women. These relationships persist both across individuals and over a person's life-cycle, indicating that inter-temporal maximisation with respect to divorce risk occurs.

The next section provides an overview of past work examining the relationship between wages, labour supply and divorce, before I present my theoretical model. After describing the NLSY dataset, I then discuss my empirical strategy and results.

\section{Literature review}

Numerous previous studies have established that married men have higher earnings than never-married men. Although it continues to be the subject of debate, one persuasive explanation for this is that married men are more productive because they are able to devote more time to labour market activities and, hence, accumulate more human capital, 
while their wives specialise in household production. ${ }^{1}$ If intra-marriage specialisation is important, one should also expect adjustments to wages and labour supply for both men and women after marriages dissolve. In general, studies indicate that divorce tends to result in higher labour force participation rates for women, although this relationship seems to have weakened over recent decades. ${ }^{2}$ Furthermore, men's wages appear to fall after divorce. $^{3}$

Haurin (1989) was notable in that he presented a model of utility maximisation that can explain the relationship between labour supply and divorce. In this model, there are two periods and women choose work hours to maximise utility in the face of uncertainty over the employment prospects of their husbands in the second period. Divorce can be viewed as one possible (extreme) shock to a husband's labour supply, since it is treated as being equivalent to a husband not working at all. Haurin shows that leisure demanded by a married woman in the second period is negatively related to the deviation of her husband's work hours from the expected amount. ${ }^{4}$ He tests this relationship using data from the National Longitudinal Survey of Mature Women. Consistent with predictions, divorce is found to induce the largest labour supply response among women, relative to widowhood or a husband's unexpected unemployment or health deterioration.

To the best of the author's knowledge, only six papers have explicitly examined the effect anticipated divorce risk has on labour supply. Greene and Quester (1982) used

\footnotetext{
${ }^{1}$ Korenman and Neumark (1991), Daniel (1992), Blackburn and Korenman (1994), Gray (1997), Chun and Lee (2001) and Cohen (2002) all found support for the so-called "productivity hypothesis", whereas Jacobsen and Rayack (1996), Loh (1996) and Hersch and Stratton (2000) concluded that productivity differences cannot explain the marriage premium. In addition, Nakosteen and Zimmer (1987), Cornwell and Rupert (1997) and Millimet et al. (2004) reported evidence in favour of the rival "selection hypothesis", whereby men who are more productive in the labour market also tend to be more likely to marry.

${ }^{2}$ Johnson and Skinner (1988) found that women increase their labour supply after divorce, although this is mostly due to an increase in labour force participation than in work hours. Seitz (1999) noted that, among whites, remarried women have higher labour force participation rates than women in their first marriage, but that there are no significant differences between the participation rates of black women who are single, divorced, married or remarried. In contrast, Bedard and Deschênes (2005) concluded that divorce has no effect on female labour force participation, although it does increase hours and weeks of work.

${ }^{3}$ Gray (1997) reported a negative relationship between wages and years since divorce or separation, although the causes of this have changed over time. Ahituv and Lerman (2005) found that for men, divorce results in a fall in wages and hours worked relative to a continuing marriage.

${ }^{4}$ It should be noted that, unlike the model presented later, Haurin explains labour supply responses to actual divorce, not the risk of divorce in the future.
} 
United States Census Bureau data to create predicted divorce probabilities for women based on their demographic characteristics, using a model of marital dissolution developed earlier by Orcutt et al. (1976). They found that among married women, labour supply increases with divorce risk.

Johnson and Skinner (1986) estimated a simultaneous model of future divorce probability and labour supply among married woman using PSID data for 1972. Their approach was to obtain predicted probabilities of future divorce from probit equations and use these in labour force participation regressions in place of actual divorce. They found that women increase their labour force participation in the three years prior to separation, noting that the increases in the divorce rate may explain one-third of the increase in female labour supply over the past half-century. Gray (1995) took a very similar approach with NLSY 1979 data for 1988 and also found that women who experience divorce within three years are more likely to work than other married women, ceteris paribus. Conversely, a married woman's labour force participation decision has no influence on her probability of divorcing within the following three years.

Like Johnson and Skinner, Montalto and Gerner (1998) examined PSID data, however they considered both men and women and used fifteen years of observations, rather than a single baseline year. A drawback of this was that only a limited number of variables were available. ${ }^{5}$ Montalto and Gerner estimated first-stage probit equations for both divorce among married people and remarriage among divorcés and divorcées. Results from their second-stage labour supply equations suggest that expectation of divorce is positively associated with labour force participation and hours among married women, while expectation of remarriage is negatively related to labour force participation by divorced women. Among men, probability of divorce reduces labour force participation and probability of remarriage increases participation.

Austen (2004) analysed Australian data and used a Cox proportional hazard model to estimate divorce hazard rates for women in 1991. She found that a 10 percentage point

\footnotetext{
${ }^{5}$ Most significantly, Montalto and Gerner have no information on respondents' marital histories. Other than the differences in functional form, their divorce probability variable is identified solely by spousal characteristics, which all other authors enter as regressors in the labour supply equation. The authors also include employment status in the divorce and remarriage probit equations, counter to the argument that this variable is endogenously determined.
} 
rise in the risk of divorce would increase the probability of a married woman working full-time by 13.8 percentage points.

Unlike the other five papers, Sen (2000) constructs a longitudinal dataset and compares two cohorts: the NLSYW for 1968-1983 and the NLSY 1979 for 1979-1993. Her measure of divorce risk was a dummy variable indicating whether divorce or separation occurred in the next three years. To control for the potential endogeneity of future divorce, Sen tried both using the age at time of marriage as an instrument and substituting the predicted probability of divorce from an unspecified probit equation in place of actual divorce. Her results suggest that the risk of divorce significantly increases labour supply, but by less in the more recent cohort. ${ }^{6}$

One further paper uses time series techniques to analyse aggregate time series data for the divorce rate and the labour force participation rate among married women. Bremmer and Kesselring (2004) found that an increase in the divorce rate results in a long-run increase in the participation rate.

In addition to these studies, a strand of literature has developed which utilises exogenous changes in divorce laws to examine the effect the costs associated with divorce have on the labour supply decisions of married women, while circumventing the problems associated with the endogeneity of these variables. These papers rely on a natural experiment, whereby states implemented "no-fault" divorce legislation at different times. No-fault laws are assumed to reduce the costs associated with divorce. Their effect on the incidence of divorce is less clear-cut and there is no consensus in the literature on whether there is a significant relationship. ${ }^{7}$

Among the papers examining the labour market effects of divorce law changes, Peters (1986) and Parkman (1992) both used Current Population Survey (CPS) data and found that no-fault divorce legislation increases labour participation rates among married women. Parkman attributed this to the fact that women who do not participate in the labour market during marriage receive less compensation for their loss of human capital

\footnotetext{
${ }^{6}$ Although both Montalto and Gerner and Sen used panel datasets, neither considered panel estimation techniques for the divorce or labour supply equations.

${ }^{7}$ Among others, Allen (1992) and Friedberg (1998) reported that no-fault laws increased the likelihood of divorce, while Peters (1986) found no effect. Recent evidence by Wolfers (2006) suggests that while divorce law reform leads to higher divorce rates during the first decade after the change in law, it has no long-term effect on the divorce rate.
} 
under no-fault laws. This is because these laws reduce the bargaining power of women and, instead, place more importance on property division laws, which recognise only physical and financial assets and ignore human capital. In response, married women in no-fault states are more likely to work in order to insulate themselves from the potential costs of divorce.

Using data from the Census, CPS and PSID, Gray (1998) extended the argument that marital property laws have an important effect on the work decisions of married women by looking at the interaction between the type of property law and no-fault legislation. He found that a move to no-fault divorce is associated with a decrease in labour supply among married women in states with property laws that tend to favour the husband but an increase in labour supply in states with property laws that tend to redistribute assets to the wife, noting that this is consistent with a bargaining model of marriage where non-market time is divided between leisure and household production. In contrast, Chiappori et al. (2002) reported that married women tend to work fewer hours in states where divorce law is favourable to women and vice versa.

\section{Theoretical model}

In this section, I present a model of labour supply in which individuals choose their hours of work in each period to maximise lifetime utility. Unmarried people take their wage rate and the probability of marriage as given, while married people take their own wage rate, their spouses' wage rate and the probability of divorce as given. Wages are determined by past hours of work. In contrast to other models of the division of labour within marriages, our approach assumes a non-cooperative relationship between spouses, so that the hours worked by each constitute a subgame-perfect Nash equilibrium. ${ }^{8}$

\section{a. Structure of model}

Consider the population of married people. In each period, their utility is strictly

\footnotetext{
${ }^{8}$ Other approaches are cooperative decision making, e.g. Daniel (1992), or cooperative bargaining, e.g. Lundberg and Pollak (1993). Lundberg and Pollak (1996) provide a comparison of the three frameworks. One previous paper that considered labour supply and marital status over the life-cycle is van der Klaauw (1996), who analysed the marriage and labour force participation decisions of women.
} 
concave in consumption, $C$, and weakly concave in home production, $H:^{9}$

$$
u(C, H)=\ln C+\delta H .
$$

Consumption is derived from one's own earnings, which are the product of wages, $w$, and hours of work, $n$, the earnings of one's spouse and the couple's non-labour income, $2 R$. A fraction of one's total income, $1-\lambda$, is conferred to one's spouse. This assumption is in contrast to the income pooling assumption made under the common preference approach to family behaviour. ${ }^{10}$ Non-wage income is shared equally between the couple, so that each receives $R$.

Home production is equal to the total hours spent at home by the married couple. It is a public good, insofar as the same amount is available for consumption by both husband and wife (see, for example, Iyigun (2005)). I do not model leisure and normalise the total hours to be devoted by each person to work and home production to be 1 . Hence, the maximum possible amount of home production for the couple in any period is 2 .

Throughout, barred variables and parameters will refer to husbands and unbarred variables will refer to wives. The wife's utility in any period, $t$, is then given by:

$$
u\left(w_{t}, n_{t}, \bar{w}_{t}, \bar{n}_{t}, R_{t}\right)=\ln \left(\lambda w_{t} n_{t}+(1-\bar{\lambda}) \bar{w}_{t} \bar{n}_{t}+R_{t}\right)+\delta\left(2-n_{t}-\bar{n}_{t}\right),
$$

and the husband's by:

$$
u\left(w_{t}, n_{t}, \bar{w}_{t}, \bar{n}_{t}, R_{t}\right)=\ln \left((1-\lambda) w_{t} n_{t}+\bar{\lambda} \bar{w}_{t} \bar{n}_{t}+\bar{R}_{t}\right)+\delta\left(2-n_{t}-\bar{n}_{t}\right),
$$

where $\bar{R}_{t}=R_{t}$.

Competitive asset markets are assumed, meaning that all non-labour income grows at the rate $r$, which can be interpreted as the interest rate:

$$
\begin{aligned}
& R_{t+1}=(1+r) R_{t} ; \\
& \bar{R}_{t+1}=(1+r) \bar{R}_{t} .
\end{aligned}
$$

In any period, log wages are assumed to be equal to one's accumulated stock of human capital. ${ }^{11}$ Each period, the stock of human capital depreciates at rate $\rho$ but is

\footnotetext{
${ }^{9}$ Allowing for a utility function that is strictly concave in $H$ complicates the model significantly. It should be noted that similar models, such as that of Iyigun (2005), feature utility functions that are weakly concave in both $C$ and $H$.

${ }^{10}$ If $\lambda=\bar{\lambda}=1 / 2$ then we would have income pooling, however, in this case, the model reduces to situation where only the spouse with the higher wage works at all.

${ }^{11}$ Equations 6 and 7 imply that wages are an increasing function of human capital.
} 
augmented by the amount $\theta n_{t}$. Hence:

$$
\begin{aligned}
& \ln w_{t+1}=(1-\rho) \ln w_{t}+\theta n_{t} ; \\
& \ln \bar{w}_{t+1}=(1-\bar{\rho}) \ln \bar{w}_{t}+\bar{\theta} \bar{n}_{t} .
\end{aligned}
$$

Between any two adjacent periods $t$ and $t+1$ there is an exogenous possibility that the pair will separate. This happens with probability $\gamma_{t}$. An unmarried woman's singleperiod utility is:

$$
u\left(w_{t}, n_{t}, R_{t}\right)=\ln \left(w_{t} n_{t}+R_{t}\right)+\delta\left(1-n_{t}\right),
$$

where $R_{t+1}=(1+r) R_{t}$ if the individual separated between periods $t$ and $t+1$, i.e. divorcing couples split non-wage income equally. An unmarried man's utility is analogous. Marriage (or remarriage) occurs between periods with probability $\eta_{t}$. Marrying couples pool their non-labour income, so that $R_{t+1}=\bar{R}_{t+1}=(1+r)\left(R_{t}+\bar{R}_{t}\right) / 2$. The marital transition probabilities are revealed at the beginning of each period and are independent, i.e. $E_{t} \gamma_{t+j}=E\left(\gamma_{t+j}\right)$ and $E_{t} \eta_{t+j}=E\left(\eta_{t+j}\right), \forall j>0$.

Utility is assumed to be time separable and all individuals are assumed to live for $T$ periods and have the same discount factor, $\beta$, so that lifetime expected utility is given by:

$$
U\left(C_{t}, H_{t}\right)=\sum_{j=0}^{T} \beta^{j} E_{t} u\left(C_{t+j}, H_{t+j}\right) .
$$

In each period, a person chooses his/her work hours in order to maximise lifetime utility, taking all other variables as given. The choice of hours determines the following period's wage. In other words, $n$ is the control variable and $w$ is a state variable.

My approach will be to solve the problem recursively, determining an exact solution for the final period first, before approximating a solution in all earlier periods.

\section{b. Solution in the final period}

An unmarried woman's problem in period $T$ can be written:

$$
V_{T}^{U}\left(w_{T}, R_{T}\right) \equiv{ }_{n_{T}}^{\max }\left\{\ln \left(w_{T} n_{T}+R_{T}\right)+\delta\left(1-n_{T}\right)\right\} .
$$

The solution to Equation 10 is: 


$$
n_{T}^{U^{*}}=\frac{1}{\delta}-\frac{R_{T}}{w_{T}}
$$

Equation 11 implies an indirect utility function of the following form:

$$
V_{T}^{U}\left(w_{T}, R_{T}\right)=\ln \frac{w_{T}}{\delta}+\delta\left(1-\frac{1}{\delta}+\frac{R_{T}}{w_{T}}\right) .
$$

Similarly, a married woman's problem in period $T$ is:

$$
V_{T}^{M}\left(w_{t}, \bar{w}_{t}, \bar{n}_{t}, R_{t}\right) \equiv \max _{n_{T}}^{\max }\left\{\ln \left(\lambda w_{T} n_{T}+(1-\bar{\lambda}) \bar{w}_{T} \bar{n}_{T}+R_{T}\right)+\delta\left(2-n_{T}-\bar{n}_{T}\right)\right\} .
$$

The solution is:

$$
n_{T}=\frac{1}{\delta}-\frac{(1-\bar{\lambda}) \bar{w}_{T} \bar{n}_{T}+R_{T}}{\lambda w_{T}} .
$$

Equation 14 represents what I will term the married woman’s “labour supply response function". This is not a labour supply function, because $\bar{n}_{t}$ is not exogenous but, rather, is determined by the utility maximisation of the woman's husband. A married man's labour supply response function is analogous to Equation 14:

$$
\bar{n}_{T}=\frac{1}{\delta}-\frac{(1-\lambda) w_{T} n_{T}+\bar{R}_{T}}{\bar{\lambda} \bar{w}_{T}} .
$$

Husband and wife determine their optimal hours of work simultaneously according to Equations 15 and 14, respectively. For a Nash equilibrium in the period $T$ subgame, both spouses must choose a level of $n$ that is a best response to the other's value. Since each labour supply response function is a linear function of the spouse's work hours, there is a unique Nash equilibrium, akin to the case of a Cournot duopoly. Making the assumption that $\lambda>1 / 2$ and $\bar{\lambda}>1 / 2$ (i.e. neither spouse gives more than half of his/her income to the other), the labour supply functions that arise are: ${ }^{12}$

$$
\begin{aligned}
& n_{T}^{M^{*}}=\frac{\bar{\lambda}}{\lambda+\bar{\lambda}-1}\left(\frac{1}{\delta}-\frac{1}{\lambda w_{T}}\left(\frac{1-\bar{\lambda}}{\delta} \bar{w}_{T}+\frac{2 \bar{\lambda}-1}{\bar{\lambda}} R_{T}\right)\right) ; \\
& \bar{n}_{T}^{M^{*}}=\frac{\lambda}{\lambda+\bar{\lambda}-1}\left(\frac{1}{\delta}-\frac{1}{\bar{\lambda} \bar{w}_{T}}\left(\frac{1-\lambda}{\delta} w_{T}+\frac{2 \lambda-1}{\lambda} \bar{R}_{T}\right)\right) .
\end{aligned}
$$

\footnotetext{
${ }^{12}$ Equations 16 and 17 make use of the fact that $R_{T}=\bar{R}_{T}$.
} 


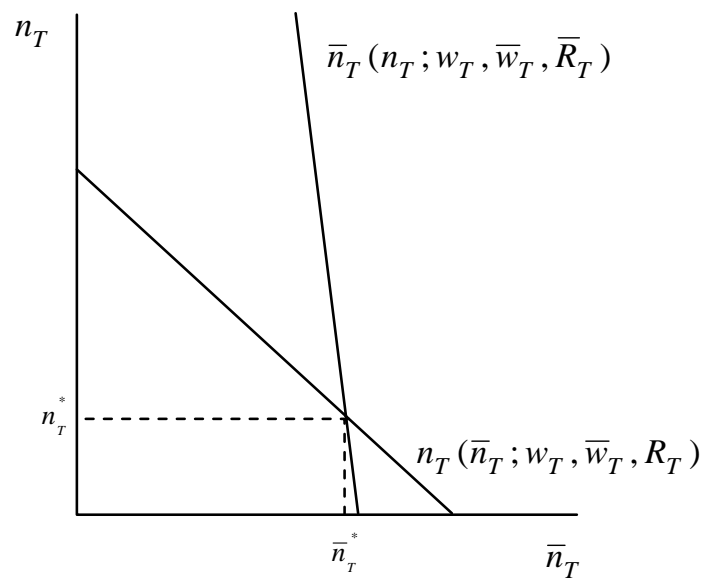

Figure 2

Nash equilibrium between the labour supply response functions of a husband and wife

To examine this equilibrium, Figure 2 plots Equations 14 and 15 together in $(n, \bar{n})$ space. Note that the wife's labour supply response function is linear in $\bar{n}$ and vice versa. The slope of the husband's curve is $-\bar{\lambda} \bar{w} /(1-\lambda) w$, while the slope of his wife's curve is $-(1-\bar{\lambda}) \bar{w} / \lambda w$. Figure 2 is drawn to illustrate the common case where $\lambda$ is close to one and $\bar{\lambda}$ is significantly less than one, i.e. the husband transfers a greater fraction of his income to his wife than he receives of her income. In this case, the husband's labour supply response curve is nearly vertical, while the wife's slopes downward somewhat.

Together, Equations 16 and 17 yield the following indirect utility function for a married woman in period $T$ :

$$
\begin{gathered}
V_{T}^{M}\left(w_{t}, \bar{w}_{t}, \bar{n}_{t}, R_{t}, \bar{R}_{t}\right)=\ln \left(\frac{\lambda w_{T}}{\delta}\right)+2 \delta-\frac{\lambda \bar{\lambda}}{\lambda+\bar{\lambda}-1}\left(2-\frac{1}{\lambda w_{T}}\left((1-\bar{\lambda}) \bar{w}_{T}+\frac{2 \bar{\lambda}-1}{\bar{\lambda}} \delta R_{T}\right)\right. \\
\left.-\frac{1}{\bar{\lambda} \bar{w}_{T}}\left((1-\lambda) w_{T}+\frac{2 \lambda-1}{\lambda} \delta \bar{R}_{T}\right)\right) .
\end{gathered}
$$

\section{c. Solution in earlier periods}

In periods $t<T$, a person's utility maximisation problem depends on the expected future utility in different marital states, as well as the probability of being in those states. For example, an unmarried woman in period $T-1$ faces the following problem: 


$$
\begin{aligned}
V_{T-1}^{U}\left(w_{T-1}, R_{T-1}\right) \equiv & { }_{n_{T-1}}^{\max }\left\{\ln \left(w_{T-1} n_{T-1}+R_{T-1}\right)+\delta\left(1-n_{T-1}\right)\right. \\
& \left.+\beta\left(\eta_{T-1} E_{T-1} V_{T}^{M}\left(w_{T}, \bar{w}_{T}, \bar{n}_{T}, \frac{R_{T}+\bar{R}_{T}}{2}\right)+\left(1-\eta_{T-1}\right) E_{T-1} V_{T}^{U}\left(w_{T}, R_{T}\right)\right)\right\}
\end{aligned}
$$

subject to:

$$
\begin{aligned}
& \ln w_{T}=(1-\rho) \ln w_{T-1}+\theta n_{T-1} ; \\
& R_{T}=(1+r) R_{T-1} ;
\end{aligned}
$$

There is no closed form solution to this problem, hence my approach is to replace $V_{T}^{M}$ and $V_{T}^{U}$ with first-order Taylor series approximations in $\ln w_{T}, \ln \bar{w}_{T}, R_{T}$ and $\bar{R}_{T}$ around the mean values, $\hat{w}, \hat{\bar{w}}, \hat{R}$ and $\hat{\bar{R}}$ :

$$
\begin{gathered}
V_{T}^{U}\left(w_{T}, R_{T}\right)=\varsigma_{T}^{U}+\left(1-\frac{\delta \hat{R}}{\hat{w}}\right) \ln w_{T}+\frac{\delta}{\hat{w}} R_{T} \\
V_{T}^{M}\left(w_{T}, \bar{w}_{T}, R_{T}, \bar{R}_{T}\right)=\varsigma_{T}^{M}+\left(1-\frac{\lambda \bar{\lambda}}{\lambda+\bar{\lambda}-1}\left(\frac{1}{\lambda \hat{w}}\left((1-\bar{\lambda}) \hat{\bar{w}}+\frac{2 \bar{\lambda}-1}{\bar{\lambda}} \delta \hat{R}\right)-\frac{(1-\lambda) \hat{w}}{\bar{\lambda} \hat{\bar{w}}}\right)\right) \ln w_{T} \\
+\frac{\lambda \bar{\lambda}}{\lambda+\bar{\lambda}-1}\left(\frac{1}{\bar{\lambda} \hat{\bar{w}}}\left((1-\lambda) \hat{w}+\frac{2 \lambda-1}{\lambda} \delta \hat{\bar{R}}\right)-\frac{(1-\bar{\lambda}) \hat{\bar{w}}}{\lambda \hat{w}}\right) \ln \bar{w}_{T} \\
+\frac{\delta}{\lambda+\bar{\lambda}-1} \frac{2 \bar{\lambda}-1}{\hat{w}} R_{T}+\frac{\delta}{\lambda+\bar{\lambda}-1} \frac{2 \lambda-1}{\frac{\hat{w}}{R_{T}}}
\end{gathered}
$$

where:

$$
\begin{aligned}
& \varsigma_{T}^{U} \equiv-\ln \delta+\delta-1+\frac{\delta \hat{R}}{\hat{w}} \ln \hat{w} ; \\
& \varsigma_{T}^{M} \equiv \ln \frac{\lambda}{\delta}+2 \delta-\frac{\lambda \bar{\lambda}}{\lambda+\bar{\lambda}-1}\left(2-\frac{(1-\bar{\lambda}) \hat{\bar{w}}}{\lambda \hat{w}}-\frac{(1-\lambda) \hat{w}}{\bar{\lambda} \hat{\bar{w}}}\right. \\
&+\left(\frac{1}{\lambda \hat{w}}\left((1-\bar{\lambda}) \hat{\bar{w}}+\frac{2 \bar{\lambda}-1}{\bar{\lambda}} \delta \hat{R}\right)-\frac{(1-\lambda) \hat{w}}{\bar{\lambda} \hat{\bar{w}}}\right) \ln \hat{w} \\
&\left.+\left(\frac{1}{\bar{\lambda} \hat{\bar{w}}}\left((1-\lambda) \hat{w}+\frac{2 \lambda-1}{\lambda} \delta \hat{\bar{R}}\right)-\frac{(1-\bar{\lambda}) \hat{\bar{w}}}{\lambda \hat{w}}\right) \ln \hat{\bar{w}}\right) .
\end{aligned}
$$

I will assume that $E_{t} \ln \bar{w}_{t+1}$ and $E_{t} \bar{R}_{t+1}$ are uncorrelated with $n_{t}, \forall t$. In other words, a single woman cannot influence the income distribution of her potential husbands by her 
work decisions. Substituting Equations 20-23 into Equation 19 and solving for $n$ then yields:

$$
n_{T-1}^{U^{*}}=\frac{1}{\delta-\varphi_{T-1}}-\frac{R_{T-1}}{w_{T-1}},
$$

where:

$$
\begin{aligned}
\varphi_{T-1} \equiv \beta \theta\left(\eta _ { T - 1 } \left(1-\frac{\lambda \bar{\lambda}}{\lambda+\bar{\lambda}-1}\left(\frac{1}{\lambda \hat{w}}\left((1-\bar{\lambda}) \hat{\bar{w}}+\frac{2 \bar{\lambda}-1}{\bar{\lambda}} \delta \hat{R}\right)\right.\right.\right. & \left.\left.-\frac{(1-\lambda) \hat{w}}{\bar{\lambda} \hat{w}}\right)\right) \\
& \left.+\left(1-\eta_{T-1}\right)\left(1-\frac{\delta \hat{R}}{\hat{w}}\right)\right) .
\end{aligned}
$$

In a similar fashion, a married woman's problem in period $T-1$ is:

$$
\begin{aligned}
V_{T-1}^{M}\left(w_{T-1}, R_{T-1}\right) & \equiv{ }_{n_{T-1}}^{\max }\left\{\ln \left(\lambda w_{T-1} n_{T-1}+(1-\bar{\lambda}) \bar{w}_{T-1} \bar{n}_{T-1}+R_{T-1}\right)+\delta\left(2-n_{T-1}-\bar{n}_{T-1}\right)\right. \\
& \left.+\beta\left(\gamma_{T-1} E_{T-1} V_{T}^{U}\left(w_{T}, R_{T}\right)\right)+\left(1-\gamma_{T-1}\right) E_{T-1} V_{T}^{M}\left(w_{T}, \bar{w}_{T}, \bar{n}_{T}, R_{T}\right)\right\},
\end{aligned}
$$

subject to:

$$
\begin{aligned}
& \ln w_{T}=(1-\rho) \ln w_{T-1}+\theta n_{T-1} ; \\
& \ln \bar{w}_{T}=(1-\bar{\rho}) \ln \bar{w}_{T-1}+\bar{\theta} \bar{n}_{T-1} ; \\
& R_{T}=(1+r) R_{T-1} ; \\
& \bar{R}_{T}=(1+r) \bar{R}_{T-1} .
\end{aligned}
$$

Once again, I approximate the period $T$ indirect utility functions with Equations 22 and 23. ${ }^{13}$ This produces the following labour supply response function:

$$
n_{T-1}=\frac{1}{\delta-\phi_{T-1}}-\frac{(1-\bar{\lambda}) \bar{w}_{T-1} \bar{n}_{T-1}+R_{T-1}}{\lambda w_{T-1}},
$$

and, for a Nash equilibrium in the period $T-1$ subgame, the following labour supply function:

$$
n_{T-1}^{M^{*}}=\frac{\lambda \bar{\lambda}}{\lambda+\bar{\lambda}-1}\left(\frac{1}{\delta-\phi_{T-1}}-\frac{1}{\lambda w_{T-1}}\left(\frac{1-\bar{\lambda}}{\delta-\bar{\phi}_{T-1}} \bar{w}_{T-1}+\frac{2 \bar{\lambda}-1}{\bar{\lambda}} R_{T-1}\right)\right),
$$

where:

\footnotetext{
${ }^{13}$ Note that here $V_{T}^{M}$ is known with certainty.
} 


$$
\begin{array}{r}
\phi_{T-1} \equiv \beta \theta\left(\left(1-\gamma_{T-1}\right)\left(1-\frac{\lambda \bar{\lambda}}{\lambda+\bar{\lambda}-1}\left(\frac{1}{\lambda \hat{w}}\left((1-\bar{\lambda}) \hat{\bar{w}}+\frac{2 \bar{\lambda}-1}{\bar{\lambda}} \delta \hat{R}\right)-\frac{(1-\lambda) \hat{w}}{\bar{\lambda} \hat{w}}\right)\right)\right. \\
\left.+\gamma_{T-1}\left(1-\frac{\delta \hat{R}}{\hat{w}}\right)\right) ; \\
\bar{\phi}_{T-1} \equiv \beta \theta\left(\left(1-\gamma_{T-1}\right)\left(1-\frac{\lambda \bar{\lambda}}{\lambda+\bar{\lambda}-1}\left(\frac{1}{\bar{\lambda} \hat{\bar{w}}}\left((1-\lambda) \hat{w}+\frac{2 \lambda-1}{\lambda} \delta \hat{\bar{R}}\right)-\frac{(1-\bar{\lambda}) \hat{\bar{w}}}{\lambda \hat{w}}\right)\right)\right. \\
\left.+\gamma_{T-1}\left(1-\frac{\delta \hat{\bar{R}}}{\hat{\bar{w}}}\right)\right) .
\end{array}
$$

Continuing to solve the problem in this recursive fashion, I can derive labour supply functions for every period. The general form for a single woman's labour supply function is:

$$
n_{t}^{U^{*}}=\frac{1}{\delta-\varphi_{t}}-\frac{R_{t}}{w_{t}},
$$

and the general forms for a married woman's labour supply response function and labour supply function are, respectively:

$$
\begin{aligned}
& n_{t}=\frac{1}{\delta-\phi_{t}}-\frac{(1-\bar{\lambda}) \bar{w}_{t} \bar{n}_{t}+R_{t}}{\lambda w_{t}}, \\
& n_{t}^{M^{*}}=\frac{\lambda \bar{\lambda}}{\lambda+\bar{\lambda}-1}\left(\frac{1}{\delta-\phi_{t}}-\frac{1}{\lambda w_{t}}\left(\frac{1-\bar{\lambda}}{\delta-\bar{\phi}_{t}} \bar{w}_{t}+\frac{2 \bar{\lambda}-1}{\bar{\lambda}} R_{t}\right)\right),
\end{aligned}
$$

where:

$$
\begin{aligned}
& \varphi_{t} \equiv\left\{\begin{array}{ll}
0 & \text { if } \mathrm{t}=T \\
\beta\left(\eta_{t} v_{t+1}^{M}+\left(1-\eta_{t}\right) v_{t+1}^{U}\right) & \text { if } t<T
\end{array} ;\right. \\
& \phi_{t} \equiv\left\{\begin{array}{lr}
0 & \text { if } \mathrm{t}=T \\
\beta\left(\left(1-\gamma_{t}\right) v_{t+1}^{M}+\gamma_{t} v_{t+1}^{U}\right) & \text { if } t<T
\end{array} ;\right. \\
& v_{t+1}^{M} \equiv \frac{\partial E_{t} V_{t+1}^{M}}{\partial n_{t}}=1-\frac{\lambda \bar{\lambda} \delta}{\lambda+\bar{\lambda}-1}\left(\frac{1}{\lambda \hat{w}}\left(\frac{1-\bar{\lambda}}{\delta-\bar{\phi}_{t+1}} \hat{\bar{w}}+\frac{2 \bar{\lambda}-1}{\bar{\lambda}} \hat{R}\right)\right. \\
& v_{t+1}^{U} \equiv \frac{\partial E_{t} V_{t+1}^{U}}{\partial n_{t}}=1-\delta \frac{\hat{R}}{\hat{w}}+\frac{(1-\rho) \varphi_{t+1}}{\theta} .
\end{aligned}
$$




\section{d. Interpreting the solution}

Equations 19 and 28 reveal that there are three components to a person's lifetime utility, as evaluated at any period $t<T$ : the utility derived from one's current earnings, the utility from contemporaneous consumption of the household good and discounted expected future utility. $\delta$ represents a person's marginal utility from an hour of household production, whereas $\varphi_{t}$ and $\phi_{t}$ represent the marginal future utility with respect to $n_{t}$ for people in different marital states. $\varphi_{t}$ and $\phi_{t}$ are time varying because the number of future periods varies and because $\gamma$ and $\eta$ change over time. I impose the constraints $\varphi_{t}<\delta$ and $\phi_{t}<\delta, \forall t$, which ensures that a married or unmarried person will work in a given period only if the prevailing wage is above some positive reservation wage. If $\varphi_{t}>\delta$ or $\phi_{t}>\delta$ then the person would choose to work the maximum number of hours in that period even if the wage was zero, because the marginal discounted future utility of an additional hour of work outweighed the marginal disutility of a one less hour of household production.

The labour supply functions embodied in Equations 37 and 39 represent two rectangular hyperbolas in $(n, w)$ space. So long as $\bar{w}_{t}>w_{t}$ and $\bar{w}_{t}>2 \delta R_{t}$ then $n_{t}^{M^{*}}$ is less curved than $n_{t}^{U^{*}}$. If, in addition, $\eta$ and $\gamma$ are both less than $1 / 2$ then the horizontal asymptote for $n_{t}^{M^{*}}$ is greater than the asymptote for $n_{t}^{U^{*}}$. In this case, there is a threshold wage, below which married women work less than unmarried women, but above which the reverse is true, as depicted in Figure 3. This illustrates intra-household specialisation: a married person with a high wage works more than an otherwise-identical single person, but a low-paid married person works less and engages in household production instead.

\section{e. Comparative statics}

I wish to examine the impact of the risk of marriage and divorce on labour supply, given the framework discussed above. Consider the derivatives of Equations 37 and 39 with respect to $\eta_{t}$ and $\gamma_{t}$, respectively: 


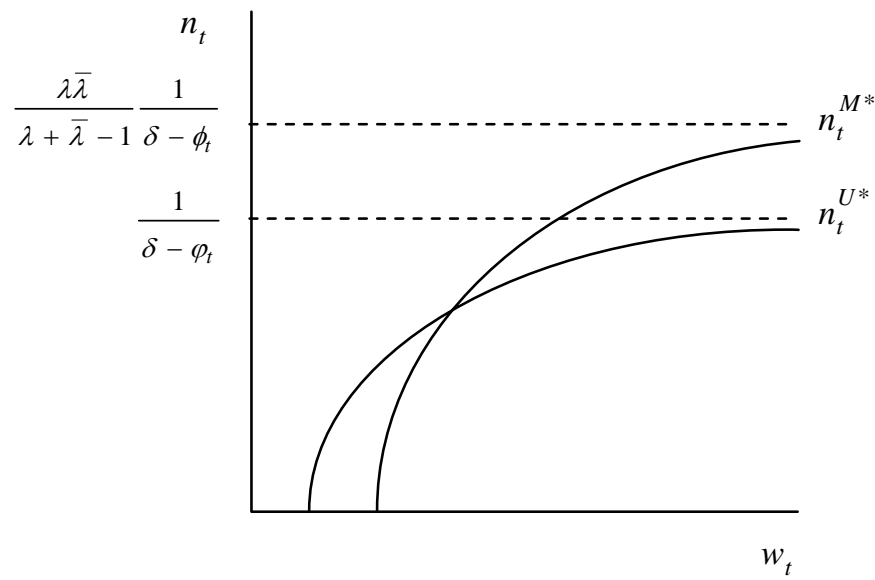

Figure 3

Labour supply functions of married and single persons

$$
\begin{aligned}
& \frac{\partial n_{t}^{U^{*}}}{\partial \eta_{t}}=\frac{\beta}{\left(\delta-\varphi_{t}\right)^{2}}\left(v_{t+1}^{M}-v_{t+1}^{U}\right) ; \\
& \frac{\partial n_{t}^{M^{*}}}{\partial \gamma_{t}}=\frac{\lambda \bar{\lambda} \beta}{\lambda+\bar{\lambda}-1}\left(\frac{v_{t+1}^{U}-v_{t+1}^{M}}{\left(\delta-\phi_{t}\right)^{2}}-\frac{(1-\bar{\lambda}) \bar{w}_{t}}{\lambda w_{t}} \frac{\bar{v}_{t+1}^{U}-\bar{v}_{t+1}^{M}}{\left(\delta-\bar{\phi}_{t}\right)^{2}}\right) .
\end{aligned}
$$

Equation 44 states that a unmarried woman will decrease her work hours in response to an increase in the likelihood of marriage if an extra hour of work would increase her expected utility more if she married than if she remained single and vice versa. The situation for married women is slightly more complicated. Equation 45 states that an increase in the probability of divorce will increase a married woman's labour supply if her marginal future utility with respect to work hours is greater when unmarried than married and her husband's marginal future utility with respect to hours is greater when married than unmarried. In Appendix 1, I prove by induction that so long as $\bar{w}_{t}>w_{t}+R_{t}$ and $\delta<1$ then $v_{t+1}^{U}>v_{t+1}^{M}$ and $\bar{v}_{t+1}^{M}>\bar{v}_{t+1}^{U}, \forall t$. This means that the derivatives in Equations 44 and 45 are unambiguously negative and positive, respectively.

Note that hours of work are also influenced by the expected marital transition probabilities in all future periods. This means, for example, that single people determine their labour supply taking into account the future likelihood of divorce. The one-periodahead "reverse" derivatives in this sense are: 


$$
\begin{gathered}
\frac{\partial n_{t}^{U^{*}}}{\partial E_{t} \gamma_{t+1}}=\frac{\beta^{2} \theta^{2} \eta_{t}}{\left(\delta-\varphi_{t}\right)^{2}}\left(\left(\frac{\lambda \bar{\lambda} \delta}{\lambda+\bar{\lambda}-1} \frac{(1-\lambda) \hat{w}}{\bar{\lambda} \hat{\bar{w}}} \frac{1}{\left(\delta-\phi_{t+1}\right)^{2}}+\frac{1-\rho}{\theta}\right)\left(v_{t+2}^{U}-v_{t+2}^{M}\right)\right. \\
\left.\quad-\frac{\lambda \bar{\lambda} \delta}{\lambda+\bar{\lambda}-1} \frac{(1-\bar{\lambda}) \hat{\bar{w}}}{\lambda \hat{w}} \frac{1}{\left(\delta-\bar{\phi}_{t+1}\right)^{2}}\left(\bar{v}_{t+2}^{U}-\bar{v}_{t+2}^{M}\right)\right)>0 ; \\
\frac{\partial n_{t}^{M^{*}}}{\partial E_{t} \eta_{t+1}}=\frac{\beta^{2} \theta^{2} \gamma_{t}}{\left(\delta-\phi_{t}\right)^{2}} \frac{\lambda \bar{\lambda}}{\lambda+\bar{\lambda}-1} \frac{1-\rho}{\theta}\left(v_{t+2}^{M}-v_{t+2}^{U}\right)<0 .
\end{gathered}
$$

Hence, ceteris paribus, single people will work more when their future divorce probabilities are high and married people will work less when their remarriage probabilities are high.

\section{f. Extensions to the model}

An obvious omission of the model described above is the treatment of children. Married women may choose to stay out of the labour market not because they are less productive in paid work than their husbands but because they wish to raise a family. This could be incorporated into the model in a simple manner by modifying the utility function, Equation 2, to allow men and women to have different productivities in home production, as follows:

$$
u\left(w_{t}, n_{t}, \bar{w}_{t}, \bar{n}_{t}, R_{t}\right)=\ln \left(\lambda w_{t} n_{t}+(1-\bar{\lambda}) \bar{w}_{t} \bar{n}_{t}+R_{t}\right)+\delta\left(2-\alpha n_{t}-\overline{\alpha \bar{n}_{t}}\right),
$$

where $\alpha$ and $\bar{\alpha}$ are the maximum amounts of the household good that the wife and husband could produce, respectively. If one treats child-rearing as a component of the household public good, then one might assume that $\alpha>1 \geq \bar{\alpha}$. In this case, the above analysis will hold, except that $\delta$ is replaced in the labour supply functions with $\alpha \delta$ or $\bar{\alpha} \delta$ where appropriate. This means that both married and unmarried women will work less than under the assumption of equal home productivity.

Another unrealistic assumption of the model is that the marital transition probabilities are exogenous, when they are likely to be functions of the chosen hours of work. This will be an important consideration in the empirical analysis in Section 5. The above model can be modified so that the transition probabilities are functions of the hours in all previous periods:

$$
\gamma_{t}=\gamma\left(n_{1}, \ldots, n_{t-1}\right)
$$




$$
\eta_{t}=\eta\left(n_{1}, \ldots, n_{t-1}\right) \text {. }
$$

In this case, the key derivatives in Equations 44 and 45 will be unchanged, although the derivative of hours with respect to future transition probabilities will be altered. The fully endogenous case where $\gamma_{t}$ and $\eta_{t}$ are functions of contemporaneous work hours is more complicated and may give rise to multiple equilibria. ${ }^{14}$

\section{Data}

The empirical analysis uses data for 1979-2004 from the NLSY 1979, which is a nationally representative sample of 12,686 young men and women who were 14-22 years old when they were first surveyed in 1979. These individuals were interviewed annually until 1994 and are currently interviewed on a biennial basis. ${ }^{15}$ Like Ahituv and Lerman (2005), I dropped the military over-sample and the low-income white over-sample, which were discontinued in 1986 and 1991, respectively, and together comprise 2,923 individuals. This left a sample of 4,837 males and 4,926 females, containing 54,481 male person-year observations and 58,764 female person-year observations.

The NLSY questionnaire contains detailed information on the timing of past changes in marital status, allowing the creation of a complete marital history for each person. I consider four marital states: never married, married for the first time, remarried and divorced or separated. ${ }^{16}$

The annual earnings and hours worked by a respondent and his/her spouse during the year prior to each interview are available and a wage variable was constructed from these. For those who did not work in a given year, had missing income or work hours data, received self-employment income or had a wage less than $\$ 2$ or greater than $\$ 200$, I interpolated a wage rate using information on the person's wage rate in previous and future periods. For observations that could not be interpolated, I inserted the nearest valid

\footnotetext{
${ }^{14}$ One could imagine a scenario where there is a low $n /$ low $\gamma$ equilibrium and a high $n / h$ igh $\gamma$ equilibrium.

${ }^{15}$ Ahituv and Lerman (2005) were able to construct an annual panel, using the retrospective information that was provided by respondents after the switch to biennial surveys. Although this allows the construction of complete marital status, work hours and wage series, it is not possible to recover spousal characteristics for the missing years.

${ }^{16}$ Separation is grouped with divorce as the predictions discussed in the previous section are driven by the division of labour within a shared household, not any legal definition of marriage. Separations that last less than a year are ignored in the hazard models in Section 5.
} 
observation. ${ }^{17}$ All monetary values are expressed in 2000 dollars, using the National Income and Product Account price index for personal consumption expenditures.

Other variables that are used in the labour supply regressions include race/ethnicity; age; highest schooling grade completed; percentile score on the Armed Forces Qualification Test (AFQT); family rent, dividend and interest income; region of residence; urban status; whether the respondent was born in a foreign country; whether the respondent's health limited the amount of work he/she could perform; number of children in household and presence of a child aged under 6 in the household; and the local unemployment rate. In addition, an index measuring attitudes towards the roles of men and women is constructed from eight questions asked of the respondent during the 1982 interview using factor analysis. ${ }^{18}$

Additional variables that are used in the marital transition equations are current religion of the respondent and whether he/she attends religious services weekly; whether the respondent's parents separated before age 18; the age a respondent expects to get married for the first time, as asked in 1979; actual age at marriage and whether the respondent had a child at present in the household at time of marriage.

Means for some of the key variables used in the labour supply regressions are presented in Table 1, including the marital transition hazard rates, which will be described in the next section. Each observation here represents a person-year combination and the sample is restricted to ages 25 and above. Note that the male sample features a considerably higher percentage of never-married observations. This is because women tend to marry for the first time at younger ages than men.

\footnotetext{
${ }^{17}$ Imputing missing wage observations using ordinary least squares and fixed effects regression models instead made little difference to the results presented in the following section.

${ }^{18}$ The statements the respondents were asked to evaluate on a four-point scale were: "a woman's place is in the home, not in the office or shop", "a wife who carries out her full family responsibilities doesn't have time for outside employment”, “a working wife feels more useful than one who doesn't hold a job", "employment of wives leads to more juvenile delinquency", "employment of both parents is necessary to keep up with the high cost of living", "it is much better for everyone concerned if the man is the achiever outside the home and the woman takes care of the home and family", "men should share the work around the house with women, such as doing dishes, cleaning and so forth" and "women are much happier if they stay at home and take care of their children".
} 
Table 1

Means for the labour supply equation estimation sample

\begin{tabular}{|l|c|c|}
\hline Variable & Females & Males \\
\hline Annual hours of work & 1512.711 & 2154.311 \\
Employed & 0.848 & 0.968 \\
Never married & 0.258 & 0.374 \\
First marriage & 0.534 & 0.502 \\
Subsequent marriage & 0.051 & 0.027 \\
Divorced & 0.157 & 0.097 \\
Wage & 13.105 & 16.699 \\
Spouse wage & 20.531 & 13.914 \\
Non-wage income (in 1000s) & 1.274 & 3.289 \\
Age & 31.004 & 30.595 \\
Black non-Hispanic & 0.146 & 0.129 \\
Hispanic & 0.055 & 0.057 \\
Highest grade completed & 14.006 & 13.760 \\
AFQT score & 50.210 & 52.417 \\
Foreign born & 0.035 & 0.038 \\
Midwest & 0.289 & 0.331 \\
South & 0.348 & 0.315 \\
West & 0.169 & 0.173 \\
Urban & 0.816 & 0.806 \\
Local unemployment rate & 0.066 & 0.067 \\
Number of children & 1.237 & 0.847 \\
Child under 6 & 0.416 & 0.347 \\
First marriage hazard & 0.070 & 0.070 \\
First divorce hazard & 0.011 & 0.006 \\
Subsequent marriage hazard & 0.045 & 0.043 \\
Subsequent divorce hazard & 0.002 & 0.000 \\
\hline Number of observations & 25,552 & 22,851 \\
\hline Ni & 2525 & \\
\hline
\end{tabular}

Notes: Means are calculated using the 1979 sampling weights.

Wages and incomes are in constant (2000) dollar values, using the personal consumption expenditures price index from the National Income and Product Accounts.

\section{Approach and results}

The primary analysis is concerned with estimating labour supply functions for married and unmarried individuals, controlling for the probability of exiting one's current marital state. To facilitate estimation, I linearise Equations 37 and 39 in $\ln w_{t}, \ln \bar{w}_{t}, R_{t}$, $\bar{R}_{t}, \eta_{t}$ and $\gamma_{t}$ and combine them in a single expression. To allow for heterogeneity among individuals, $i$, I also condition on demographic factors, $\mathbf{X}$, and introduce an error term, $\varepsilon$ :

$$
\begin{aligned}
& n_{i t}=\chi_{0 j}+\chi_{1 j} \ln w_{i t}+\chi_{2 j} \ln \bar{w}_{i t}+\chi_{3 j} R_{i t}+\chi_{4 j} \eta_{i t}+\chi_{5 j} \gamma_{i t}+\mathbf{X}_{i t} \boldsymbol{\pi}_{j}+\varepsilon_{i t} ; \\
& \bar{n}_{i t}=\bar{\chi}_{0 j}+\bar{\chi}_{1 j} \ln \bar{w}_{i t}+\bar{\chi}_{2 j} \ln w_{i t}+\bar{\chi}_{3 j} \bar{R}_{i t}+\bar{\chi}_{4 j} \eta_{i t}+\bar{\chi}_{5 j} \gamma_{i t}+\overline{\mathbf{X}}_{i t} \overline{\boldsymbol{\pi}}_{j}+\bar{\varepsilon}_{i t} .
\end{aligned}
$$

The linearised coefficients for women are: 


$$
\begin{aligned}
\chi_{0 j} \equiv & I_{j}\left(\frac{1}{\delta-\hat{\phi}}-\frac{(1-\bar{\lambda}) \hat{\bar{w}}}{\lambda \hat{w}}\left(\frac{1}{\delta-\hat{\bar{\phi}}}\right)-\left(\frac{(1-\bar{\lambda}) \hat{\bar{w}} \hat{\bar{n}}+\hat{R}}{\lambda \hat{w}}+\frac{(1-\lambda)(1-\bar{\lambda}) \hat{n}}{\lambda \bar{\lambda}}\right) \ln \hat{w}\right. \\
& \left.+\left(\frac{(1-\bar{\lambda}) \hat{\bar{w}} \hat{\bar{n}}}{\lambda \hat{w}}+\frac{(1-\bar{\lambda})((1-\lambda) \hat{w} \hat{n}+\hat{\bar{R}})}{\lambda \bar{\lambda} \hat{w}}\right) \ln \hat{\bar{w}}\right)+\left(1-I_{j}\right)\left(\frac{1}{\delta-\hat{\varphi}}-\frac{\hat{R}}{\hat{w}} \ln \hat{w}\right) ; \\
\chi_{1 j} \equiv & \frac{1}{\hat{w}}\left(I_{j}\left(\frac{(1-\bar{\lambda}) \hat{\bar{w}} \hat{\bar{n}}+\hat{R}}{\lambda}+\frac{(1-\lambda)(1-\bar{\lambda}) \hat{w} \hat{n}}{\lambda \bar{\lambda}}\right)+\left(1-I_{j}\right) \hat{R}\right) ; \\
\chi_{2 j} \equiv & -\frac{(1-\bar{\lambda})}{\lambda \hat{w}}\left(\hat{\bar{w}} \hat{\bar{n}}+I_{j} \frac{(1-\lambda) \hat{w} \hat{n}+\hat{R}}{\bar{\lambda}}\right) ; \\
\chi_{3 j} \equiv & -\frac{1}{\lambda \hat{w}}\left(1+I_{j} \frac{1-\bar{\lambda}}{\bar{\lambda}}\right) ; \\
\chi_{4 j} \equiv & \left(1-I_{j}\right) \beta \theta \frac{\hat{v}^{M}-\hat{v}^{U}}{(\delta-\hat{\varphi})^{2}} ; \\
\chi_{5 j} \equiv & I_{j} \beta \theta\left(\frac{\hat{v}^{U}-\hat{v}^{M}}{(\delta-\hat{\phi})^{2}}-\frac{\hat{\bar{v}}^{U}-\hat{\bar{v}}^{M}}{\left(\delta-\hat{\bar{\phi}}^{2}\right.}\right),
\end{aligned}
$$

where $j$ indexes marital state and $I_{j}$ is an indicator function for being married. Different specifications of $\varepsilon$ will be considered.

In all estimates of Equations 51 and 52 discussed in this section, the dependent variable is annual hours of work in the previous year. The imputed log wage and family non-wage income are included, along with their interactions with all marital states. ${ }^{19}$ The spouse's imputed wage is interacted with first and subsequent marriage. Additional controls include education, the gender roles index, number of own children in household and whether the youngest child was under 6, which are interacted with all marital states; spouse education and the age difference between spouses, which are interacted with first and subsequent marriages; as well as race/ethnicity, AFQT score, urban status, foreign born status, health status, whether attending regular school, and the local unemployment rate. In order to focus on those who have completed the majority of their schooling, I drop those observations before age 25.

Obviously, an individual's probability of changing marital state is unknown to the

\footnotetext{
${ }^{19}$ Since I use family income, one would expect the coefficients on the interaction terms to be negative, even if the non-wage income elasticity of labour supply was the same for single and married people.
} 
Table 2

Estimates of labour supply equations using CPS divorce and marriage rates

\begin{tabular}{|c|c|c|c|c|}
\hline Variable & $\begin{array}{c}\text { (i) } \\
\text { OLS } \\
\text { Females }\end{array}$ & $\begin{array}{c}\text { (ii) } \\
\text { Tobit } \\
\text { Females }\end{array}$ & $\begin{array}{c}\text { (iii) } \\
\text { OLS } \\
\text { Males }\end{array}$ & $\begin{array}{c}\text { (iv) } \\
\text { Tobit } \\
\text { Males }\end{array}$ \\
\hline Never married $\times$ marriage rate & $\begin{array}{l}728.111 * * * \\
(260.868)\end{array}$ & $\begin{array}{c}951.490 * * * \\
(319.759)\end{array}$ & $\begin{array}{l}1109.441^{* * *} \\
(162.087)\end{array}$ & $\begin{array}{c}1397.441^{* * *} \\
(174.744)\end{array}$ \\
\hline First marriage $\times$ divorce rate & $\begin{array}{c}428.421 * * * \\
(85.176)\end{array}$ & $\begin{array}{c}475.511^{* * *} \\
(104.041)\end{array}$ & $\begin{array}{c}38.092 \\
(99.968) \\
\end{array}$ & $\begin{array}{c}38.043 \\
(106.661) \\
\end{array}$ \\
\hline $\begin{array}{l}\text { (Pseudo) R-squared } \\
\text { Number of observations }\end{array}$ & $\begin{array}{c}0.159 \\
35,275\end{array}$ & $\begin{array}{c}0.013 \\
35,275\end{array}$ & $\begin{array}{c}0.155 \\
31,052\end{array}$ & $\begin{array}{c}0.010 \\
33,891\end{array}$ \\
\hline
\end{tabular}

Note: Controls also include own and spouse log wage, non-wage income, own and spouse highest grade completed, age difference between spouses, attitude to gender roles, number of children and child under 6, all interacted with marital status, plus age, age squared, black non-Hispanic, Hispanic, attended school, AFQT score, poor health, foreign born, 3 region dummies, urban, local unemployment rate and marital status dummies.

Standard errors are presented in parentheses. *, ** and *** denote significance at the $10 \%, 5 \%$ and $1 \%$ level, respectively.

researcher. One approach is to use as a proxy the divorce rate among people with similar characteristics. The June supplement of the Current Population Survey contains information on the age of respondents at first marriage and divorce. From the 1980 supplement, I calculated the proportion of first marriages that end (by divorce or widowhood) within ten years for each combination of region, education, race/ethnicity and age at marriage category. ${ }^{20}$ As a measure of marriage, I calculated the fraction of people who had married by the age of 30 within region, education, race/ethnicity and sex categories. Table 2 presents the results of using these estimates as measures of $\gamma$ and $\eta$ in Equations 51 and 52. Consistent with the model presented in Section 3, the divorce rate is seen to have a significant positive effect on the hours worked by women in their first marriage but an insignificant effect on hours for men. Furthermore, the marriage rate is positively associated with hours for never-married men. However, contrary to the predictions of the model, the marriage rate also has a positive impact on the hours worked by never-married women.

A problem with these measures of the marital transition probabilities is that they do not take account of the specific characteristics of each individual or married couple.

\footnotetext{
${ }^{20}$ I use three education categories (less than Grade 12, Grade 12, at least some college), three race/ethnicity categories (white non-Hispanic, black non-Hispanic and Hispanic) and three age at marriage categories (15-20, 21-25 and 26 or over).
} 
Table 3

Average hours of work for divorcing and non-divorcing couples

\begin{tabular}{|l|c|c|c|c|}
\hline \multirow{2}{*}{ Year relative to divorce } & \multicolumn{2}{|c|}{ Females } & \multicolumn{2}{c|}{ Males } \\
\cline { 2 - 5 } & Divorcers & Non-divorcers & Divorcers & Non-divorcers \\
\hline-3 & 1262 & 1220 & 1968 & 2077 \\
-2 & 1309 & 1218 & 2067 & 2080 \\
-1 & 1348 & 1220 & 2075 & 2079 \\
0 & 1425 & 1221 & 2107 & 2084 \\
1 & 1579 & 1219 & 2215 & 2086 \\
2 & 1619 & 1216 & 2018 & 2073 \\
\hline
\end{tabular}

Notes: The divorcing sample consists of those who were observed both 3 years before and 2 years after their first marriage ended.

The non-divorcing sample consists of all individuals in their first marriage who are not observed to separate and reflects the age composition of the divorcing sample at a particular year relative to divorce.

All means are weighted using the 1979 sample weights.

Furthermore, they do not reflect the ways in which the risk of divorce evolves over the course of a marriage. Hence, the results in Table 2 only reflect cross-sectional differences in divorce likelihood, not inter-temporal variation. Exploiting the longitudinal nature of the NLSY, an alternative approach is to use a person's actual experience of divorce in the future. Table 3 reports average hours for a sample of divorcing men and women at different times before and after divorce, along with a comparison group of non-divorcing people with the same age composition. Among women who divorce, annual hours are seen to increase sharply, from 1262 three years before the separation to 1619 two years after it. Almost half of this adjustment occurs before divorce. In contrast, the comparison group works less in all periods and exhibits no pattern over time. Among divorcing men, the situation is less clear. Although there is evidence of a spike in hours immediately before and after divorce, these men both begin and end the period of analysis working less than the comparison group.

To control for other relevant factors that might vary between divorcing and nondivorcing people, Table 4 presents the results of estimating Equations 51 and 52 using the actual experience of changes in marital state in the following year as measures of $\gamma$ and $\eta$. The results for men are consistent with predictions for all marital transitions. For women, there is evidence of increased work hours in the year prior to the dissolution of a first marriage. However, there is no evidence of decreased hours before first marriage and, in fact, women appear to behave similarly to men by working longer hours in the lead-up to 
Table 4

Estimates of labour supply equations using actual marriage and divorce in the following year

\begin{tabular}{|l|c|c|c|c|}
\hline Variable & (i) & (ii) & (iii) & (iv) \\
& OLS & Tobit & OLS & Tobit \\
& Females & Females & Males & Males \\
\hline Never married × marriage & $103.425^{* *}$ & $127.184^{* * *}$ & $241.023^{* * *}$ & $255.418^{* * *}$ \\
& $(41.832)$ & $(49.386)$ & $(37.060)$ & $(39.137)$ \\
First marriage $\times$ divorce & $91.579^{*}$ & $118.957^{* *}$ & $-104.571^{* *}$ & $-108.845^{*}$ \\
& $(47.468)$ & $(56.134)$ & $(52.713)$ & $(55.661)$ \\
Divorced $\times$ remarriage & $82.131^{*}$ & $117.040^{* *}$ & $182.984^{* * *}$ & $187.726^{* * *}$ \\
& $(49.321)$ & $(58.179)$ & $(57.715)$ & $(60.986)$ \\
Subsequent marriage $\times$ divorce & 89.761 & 135.520 & $-224.305^{* *}$ & $-241.696^{* *}$ \\
& $(91.993)$ & $(108.486)$ & $(108.091)$ & $(114.261)$ \\
\hline R-squared & 0.166 & 0.014 & 0.152 & 0.011 \\
Number of observations & 43,247 & 43,247 & 38,484 & 38,484 \\
\hline
\end{tabular}

Note: Controls also include own and spouse log wage, non-wage income, own and spouse highest grade completed, age difference between spouses, attitude to gender roles, number of children and child under 6, all interacted with marital status, plus age, age squared, black non-Hispanic, Hispanic, attended school, AFQT score, poor health, foreign born, 3 region dummies, urban, local unemployment rate and marital status dummies.

Standard errors are presented in parentheses. $*$, ** and *** denote significance at the $10 \%, 5 \%$ and $1 \%$ level, respectively.

a subsequent marriage.

As noted by previous authors, future experience of marriage and divorce are poor measures of the transition probabilities for two reasons. Firstly, at the time they make their labour supply decisions, individuals do not know with certainty that they will change marital state. More importantly, past work has found that past hours of work are important determinants of divorce, implying that the estimates in Table 4 will suffer from endogeneity bias. To date, no empirical research has considered marriage probabilities, however, in order to isolate the causal effect of divorce risk on labour supply, previous United States studies have proxied for the former by using probit models to estimate the probability of an individual actually becoming divorced within a specified time. ${ }^{21}$ I take a somewhat different approach and estimate both marriage and divorce probabilities using Cox proportional hazard models. These allow non-parametric estimates of the marital transition probabilities (or hazard rates) at different lengths of time in the current marital state. In contrast, previous authors have typically treated years since marriage in a parametric manner by including it as a quadratic term in the divorce probit equations.

${ }^{21}$ Johnson and Skinner (1986) used the probability of divorce within three years, a decision which Gray (1995) and Sen (2000) both subsequently adopted. 
Table 5

Hazard ratios from Cox proportional hazard model estimates for the probability of divorce

\begin{tabular}{|l|c|c|c|c|}
\hline Variable & $\begin{array}{c}\text { (i) } \\
\text { Females - first } \\
\text { divorce }\end{array}$ & $\begin{array}{c}\text { (ii) } \\
\text { Females - } \\
\text { subsequent } \\
\text { divorce }\end{array}$ & $\begin{array}{c}\text { (iii) } \\
\text { Males - first } \\
\text { divorce }\end{array}$ & $\begin{array}{c}\text { (iv) } \\
\text { Males - } \\
\text { subsequent } \\
\text { divorce }\end{array}$ \\
\hline Age at marriage & $0.899^{* * *}$ & $0.815^{* * *}$ & $0.870^{* * *}$ & $0.691^{* * *}$ \\
Age difference & 1.005 & 0.952 & 1.014 & $1.135^{* *}$ \\
Black non-Hispanic & $1.674^{* * *}$ & 2.200 & $1.664^{* * *}$ & $16.236^{* * *}$ \\
Hispanic & 1.127 & 0.749 & $0.604^{* *}$ & 1.051 \\
Catholic & $0.637^{* *}$ & 0.731 & 1.067 & 0.352 \\
Baptist & 0.939 & 0.693 & 1.055 & $0.215^{* *}$ \\
Other protestant & 0.821 & 0.897 & 0.922 & 0.343 \\
Frequency of religious attendance & $0.805^{*}$ & 0.835 & $0.726^{* *}$ & $0.104^{* *}$ \\
Poor health & 1.142 & 1.591 & 1.534 & - \\
Highest grade completed & 0.994 & 0.987 & $0.900^{* * *}$ & 0.995 \\
AFQT score & $0.990^{* * *}$ & 0.997 & 0.997 & 0.997 \\
Spouse income (in 1000s) & 0.998 & $1.009 * *$ & 0.992 & 0.958 \\
Non-wage income (in 1000s) & 0.9998 & 0.499 & 1.010 & 1.000 \\
Parents divorced & 1.190 & 0.819 & $1.608^{* * *}$ & 0.792 \\
Urban & 1.167 & 0.629 & $1.543^{* *}$ & 0.489 \\
Child present & 0.957 & 0.399 & $0.573^{* * *}$ & 2.689 \\
Child before marriage & $1.520^{* * *}$ & 2.415 & $1.737^{* * *}$ & $0.129^{* *}$ \\
\hline Number of observations & 17,993 & 2,112 & 16,037 & 1,267 \\
Number of individuals & 2,125 & 453 & 2,033 & 314 \\
\hline
\end{tabular}

Note: $\quad *, * *$ and $* * *$ denote significance at the $10 \%, 5 \%$ and $1 \%$ level, respectively. Coefficients and standard errors are presented in Table A1.

Poor health was not included in the fourth specification as none of the men who were within twelve months of their second divorce had health limitations.

The Cox model assumes that the hazard rate can be written as:

$$
h(t, \mathbf{z})=h_{0}(t) e^{2 \boldsymbol{\beta}},
$$

where $\boldsymbol{\beta}$ is a vector of coefficients, $\mathbf{z}$ is a vector of covariates and $h_{0}(t)$ is the hazard when $\mathbf{z}=\mathbf{0}$, termed the baseline hazard function. Differences in covariates result in proportional shifts of the hazard rate. An exponentiated coefficient, $e^{\beta_{i}}$, is referred to as a hazard ratio and its magnitude relative to 1 determines whether the covariate in question increases or decreases the hazard rate.

Table 5 presents the results of hazard models for the probability of divorce occurring among married people. The explanatory variables that are used follow previous economic and demographic studies. I estimate separate models for men and women and for exit from first marriage and exit from subsequent marriages. In all cases, individuals who marry at older ages are less likely to divorce. Non-Hispanic blacks, those who attend 
Figure 4

Kernel plots of average divorce hazards

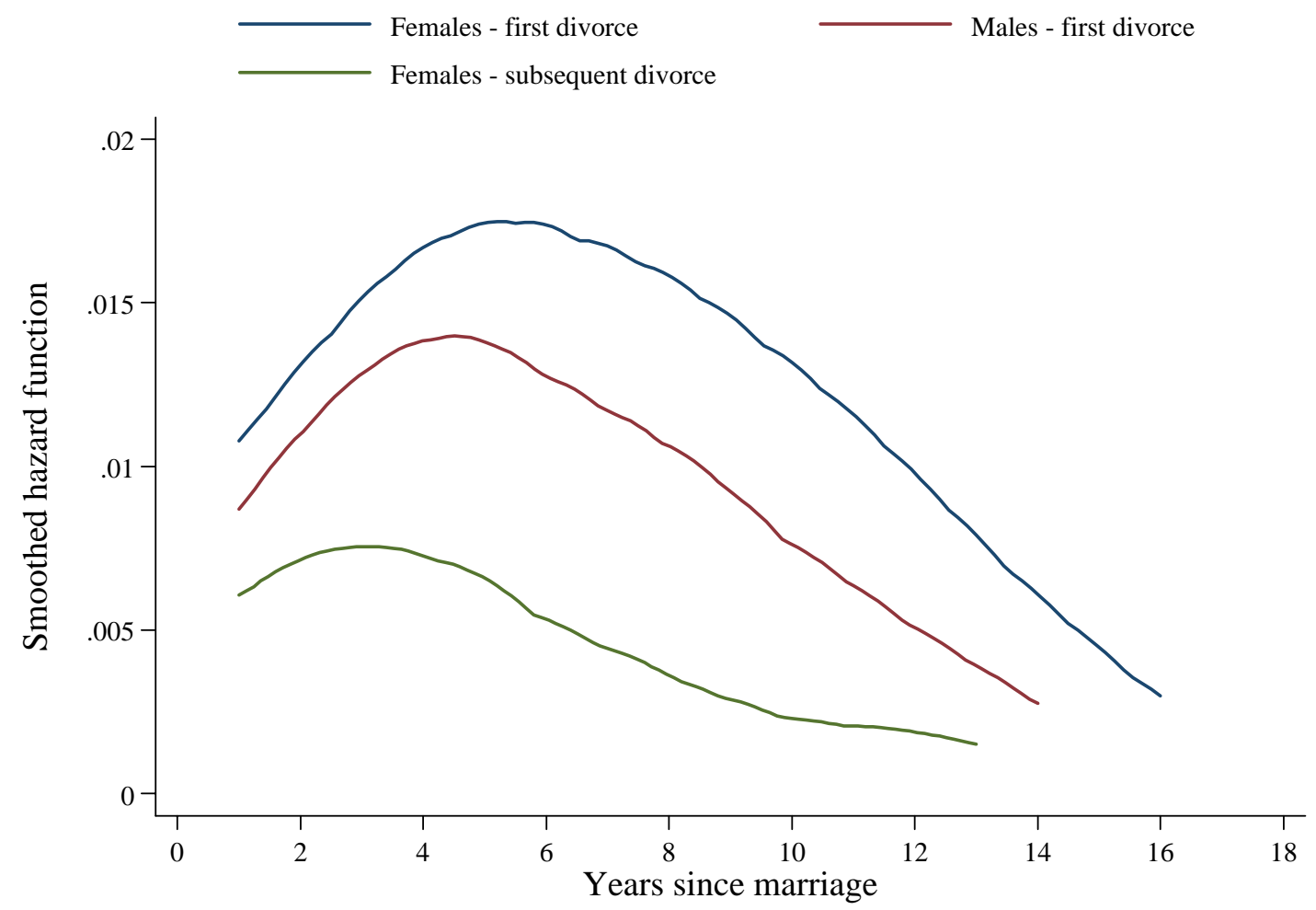

Notes: Hazard rates are estimated by setting all independent variables equal to their means.

The Epanechnikov kernel is used.

religious services weekly and those with children in the household at time of marriage are more likely to exit first marriages. Among women in their first marriages, Catholics and those with high AFQT scores also tend to have lower divorce hazards; for men, being Hispanic, not experiencing divorce as a child, living in a metropolitan area and having dependent children in the household all reduce the chances of exiting a first marriage. These results are broadly consistent with those of hazard model analyses of divorce, such as Balakrishnan et al. (1987) and Castro Martin and Bumpass (1989).

Figure 4 depicts the hazard rates for men and women in their first marriage and women in subsequent marriages, where all explanatory variables are set equal to their means. The hazard function for men in subsequent marriages is not presented as it is implausibly high, presumably because so few remarried men are observed during the sample period. The average woman is more likely to divorce than an average man who 
Table 6

Hazard ratios from Cox proportional hazard model estimates for the probability of marriage and remarriage

\begin{tabular}{|l|c|c|c|c|}
\hline Variable & $\begin{array}{c}\text { (i) } \\
\text { Females - first } \\
\text { marriage }\end{array}$ & $\begin{array}{c}\text { (ii) } \\
\text { Females - } \\
\text { subsequent } \\
\text { marriage }\end{array}$ & $\begin{array}{c}\text { (iii) } \\
\text { Males - first } \\
\text { marriage }\end{array}$ & $\begin{array}{c}\text { (iv) } \\
\text { Males - } \\
\text { subsequent } \\
\text { marriage }\end{array}$ \\
\hline Black non-Hispanic & $0.532^{* * *}$ & $0.288^{* * *}$ & $0.520^{* * *}$ & $0.559^{* *}$ \\
Hispanic & 0.908 & 1.053 & 0.962 & 1.341 \\
Catholic & 0.962 & $0.575^{* * *}$ & $0.789 * * *$ & 0.876 \\
Baptist & 1.048 & 0.987 & 0.973 & 1.138 \\
Other protestant & 0.948 & 1.051 & $0.867 * *$ & 1.207 \\
Frequency of religious attendance & $1.134^{* * *}$ & 1.188 & $1.147^{* * *}$ & 1.302 \\
Poor health & 0.967 & $0.511^{*}$ & 0.925 & 1.028 \\
Highest grade completed & $0.931^{* * *}$ & 1.048 & $0.953^{* * *}$ & $1.151^{* *}$ \\
AFQT score & 1.001 & 0.999 & $1.003^{* *}$ & 0.998 \\
Non-wage income (in 1000s) & $1.012^{* *}$ & 0.977 & 0.9997 & 0.974 \\
Parents divorced & 0.915 & 0.913 & 0.924 & 0.751 \\
Urban & $0.863^{* * *}$ & 0.903 & $0.835^{* * *}$ & 0.718 \\
Child present & $0.766^{* * *}$ & $0.558^{* * *}$ & $1.205^{*}$ & 1.099 \\
Expected marriage age & $0.749^{* * *}$ & $0.770^{* * *}$ & $0.819^{* * *}$ & 0.879 \\
\hline Number of observations & 28,345 & 5,885 & 33,323 & 3,546 \\
Number of individuals & 3,393 & 1,177 & 3,565 & 823 \\
\hline
\end{tabular}

Note: $\quad *, * *$ and $* * *$ denote significance at the $10 \%, 5 \%$ and $1 \%$ level, respectively.

Coefficients and standard errors are presented in Table A2.

has been married for the same time. The hazard rates peak between four and five years after marriage. Remarried women are less likely to divorce than women in their first marriage.

I also estimate hazard models for entry into marriage and the results of these are presented in Table 6. For entry into first marriage, age 15 was chosen as the origin because the minimum legal age for marriage without a court order (but with parental consent) in most states is $16 .^{22}$ Non-Hispanic blacks are seen to be less likely to marry or remarry. More educated and less devout persons, city-dwellers and those who expected to marry later are all less likely to marry at a given age. Interestingly, the presence of a child in the household decreases the likelihood of a woman marrying, but increases the likelihood of a man marrying. Having considerable non-wage income renders a woman more likely to marry. Among men, being Catholic or Protestant other than Baptist and having a higher AFQT score are associated with a higher probability of marriage. Again, these results largely agree with those of previous studies of marriage and remarriage,

\footnotetext{
${ }^{22} 91$ women and 5 men in the NLSY dataset married before age 15, which in most states would require a court order in addition to parental consent. These observations are excluded from the analysis in Table 3.
} 
Figure 5

Kernel plots of average marriage hazards

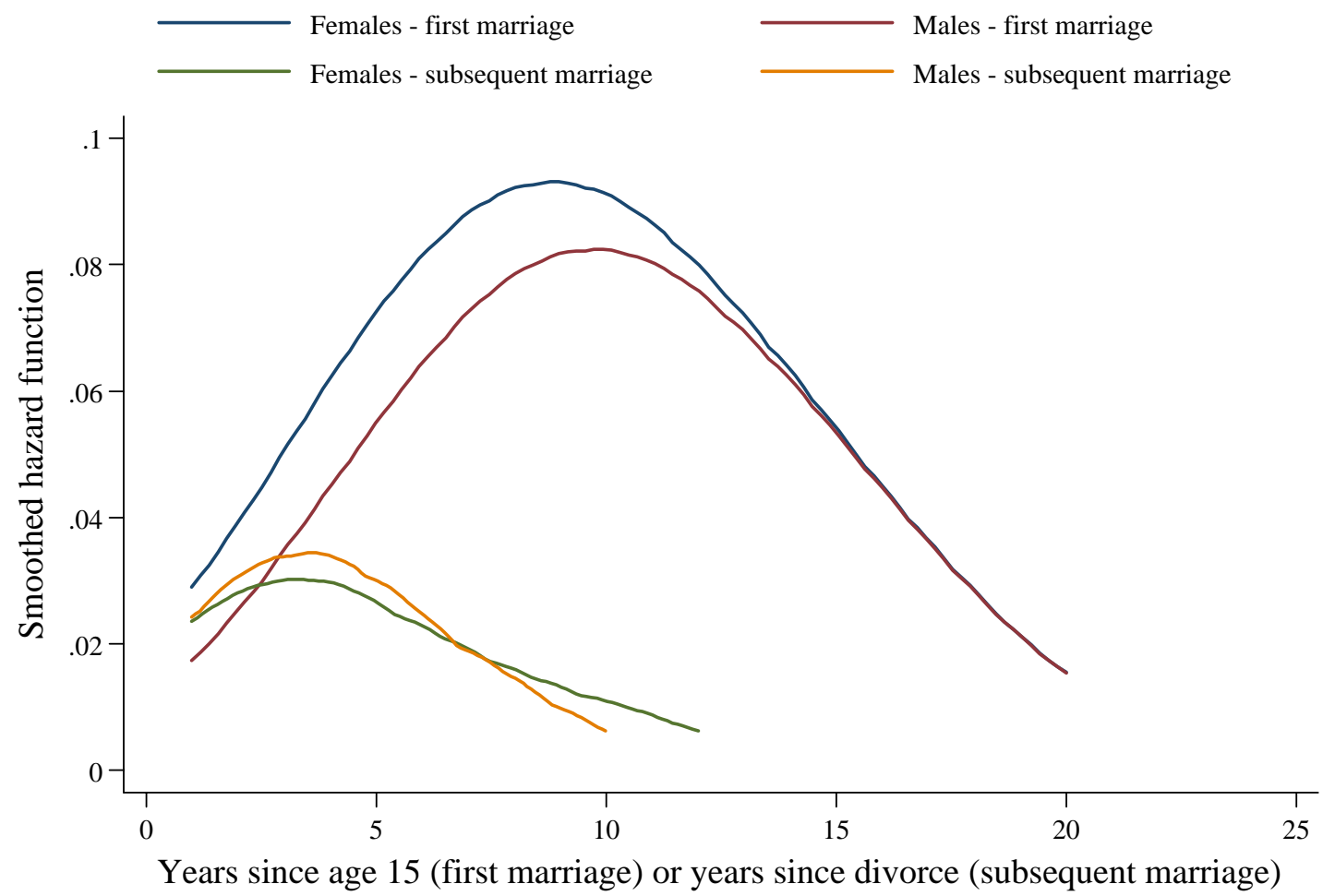

Notes: Hazard rates are estimated by setting all independent variables equal to their means. The Epanechnikov kernel is used.

such as Michael and Brandon Tuma (1985) and Koo et al. (1984).

The average marriage hazard functions for the four cases are plotted in Figure 5. Not surprisingly, women are more likely than men to marry at younger ages. The probability of marriage is highest at age 24 for women and 25 for men. The probability of remarriage peaks four years after divorce, with men being more likely to remarry rapidly.

Estimates of marriage and divorce probabilities for each person-year observation ( $\eta$ and $\gamma$ in the model presented in Section 3) are obtained from the hazard models in Tables 2 and 3 by computing the baseline hazard and multiplying it by the exponentiated linear prediction, as in Equation 59. These predicted probabilities are then interacted with the appropriate marital state (never married, first marriage, divorced or subsequent marriage) and are used as regressors in labour supply regressions, as reported in Table 7. Other than the marital transition probabilities, the specification is the same as in Tables 2 and 4. 
Table 7

Estimates of labour supply equations using estimated marriage and divorce hazard rates

\begin{tabular}{|c|c|c|c|c|}
\hline Variable & $\begin{array}{c}\text { (i) } \\
\text { OLS } \\
\text { Females }\end{array}$ & $\begin{array}{c}\text { (ii) } \\
\text { Tobit } \\
\text { Females }\end{array}$ & $\begin{array}{c}\text { (iii) } \\
\text { OLS } \\
\text { Males }\end{array}$ & $\begin{array}{c}\text { (iv) } \\
\text { Tobit } \\
\text { Males }\end{array}$ \\
\hline Log wage & $\begin{array}{c}232.331 * * * \\
(19.255)\end{array}$ & $\begin{array}{c}288.858 * * * \\
(23.086)\end{array}$ & $\begin{array}{c}8.436 \\
(14.968)\end{array}$ & $\begin{array}{c}22.998 * * * \\
(15.689)\end{array}$ \\
\hline $\begin{array}{l}\text { First marriage } \times \log \\
\text { wage }\end{array}$ & $\begin{array}{c}-134.011^{* * *} \\
(23.409)\end{array}$ & $\begin{array}{l}-127.967 * * * \\
(27.992)\end{array}$ & $\begin{array}{c}-263.405^{* * *} \\
(21.238)\end{array}$ & $\begin{array}{c}-275.269 * * * \\
(15.689)\end{array}$ \\
\hline Divorced $\times$ log wage & $\begin{array}{l}-299.806 * * * \\
(28.148)\end{array}$ & $\begin{array}{l}-324.848^{* * *} \\
(33.516)\end{array}$ & $\begin{array}{l}-210.226^{* * *} \\
(29.521)\end{array}$ & $\begin{array}{c}-214.159 * * * \\
(30.903)\end{array}$ \\
\hline $\begin{array}{l}\text { Subsequent marriage } \times \\
\text { log wage }\end{array}$ & $\begin{array}{l}-359.147 * * * \\
(43.716)\end{array}$ & $\begin{array}{c}-392.550 * * * \\
(51.926)\end{array}$ & $\begin{array}{c}-656.617^{* * *} \\
(64.803)\end{array}$ & $\begin{array}{c}-672.271^{* * *} \\
(67.724)\end{array}$ \\
\hline $\begin{array}{l}\text { First marriage } \times \text { spouse } \\
\text { log wage }\end{array}$ & $\begin{array}{l}-287.461 * * * \\
(15.254)\end{array}$ & $\begin{array}{c}-356.379 * * * \\
(18.300)\end{array}$ & $\begin{array}{l}56.833^{* * *} \\
(15.029)\end{array}$ & $\begin{array}{c}56.127 * * * \\
(15.669)\end{array}$ \\
\hline $\begin{array}{l}\text { Subsequent marriage } \times \\
\text { spouse log wage }\end{array}$ & $\begin{array}{c}-111.358^{* *} \\
(49.331)\end{array}$ & $\begin{array}{c}-133.309 * * \\
(58.917)\end{array}$ & $\begin{array}{c}159.622 * * \\
(70.687)\end{array}$ & $\begin{array}{c}165.418 * * * \\
(73.891)\end{array}$ \\
\hline $\begin{array}{l}\text { Non-wage income (in } \\
1000 \text { s) }\end{array}$ & $\begin{array}{l}-5.684 \\
(3.599)\end{array}$ & $\begin{array}{l}-7.089 \\
(4.198)\end{array}$ & $\begin{array}{c}0.076 \\
(0.046)\end{array}$ & $\begin{array}{c}0.079 \\
(0.048)\end{array}$ \\
\hline $\begin{array}{l}\text { First marriage } \times \text { non- } \\
\text { wage income }\end{array}$ & $\begin{array}{c}5.585 \\
(3.600)\end{array}$ & $\begin{array}{c}0.605 \\
(4.386)\end{array}$ & $\begin{array}{c}3.672 * * * \\
(1.026)\end{array}$ & $\begin{array}{c}3.638 * * * \\
(1.069)\end{array}$ \\
\hline $\begin{array}{l}\text { Divorced } \times \text { non-wage } \\
\text { income }\end{array}$ & $\begin{array}{c}0.435 \\
(3.936)\end{array}$ & $\begin{array}{l}-0.958 \\
(4.815)\end{array}$ & $\begin{array}{l}-0.042 \\
(0.080)\end{array}$ & $\begin{array}{l}-0.044 \\
(0.083)\end{array}$ \\
\hline $\begin{array}{l}\text { Subsequent marriage } \times \\
\text { non-wage income }\end{array}$ & $\begin{array}{c}-25.180 * * * \\
(9.648)\end{array}$ & $\begin{array}{l}-35.874 * * * \\
(12.551)\end{array}$ & $\begin{array}{c}5.031 \\
(5.955)\end{array}$ & $\begin{array}{c}4.579 \\
(6.217)\end{array}$ \\
\hline First marriage & $\begin{array}{c}1668.640 * * * \\
(109.995)\end{array}$ & $\begin{array}{l}1919.989 * * * \\
(131.512)\end{array}$ & $\begin{array}{l}1131.001^{* * *} \\
(98.711)\end{array}$ & $\begin{array}{c}1204.453^{* * * *} \\
(103.100)\end{array}$ \\
\hline Divorced & $\begin{array}{l}722.850 * * * \\
(124.596)\end{array}$ & $\begin{array}{l}777.278 * * * \\
(148.525)\end{array}$ & $\begin{array}{l}219.028 * \\
(131.024)\end{array}$ & $\begin{array}{l}228.647^{*} \\
(137.263)\end{array}$ \\
\hline Subsequent marriage & $\begin{array}{c}1379.896 * * * \\
(234.812)\end{array}$ & $\begin{array}{l}1518.297 * * * \\
(278.954)\end{array}$ & $\begin{array}{c}1317.643^{* * *} \\
(322.318)\end{array}$ & $\begin{array}{c}1355.084 * * * \\
(336.781)\end{array}$ \\
\hline $\begin{array}{l}\text { Never married } \times \\
\text { marriage probability }\end{array}$ & $\begin{array}{c}3853.004 * * * \\
(406.330) \\
{[571.646]}\end{array}$ & $\begin{array}{c}4351.235 * * * \\
(481.015) \\
{[496.046]}\end{array}$ & $\begin{array}{c}2169.397 * * * \\
(347.241) \\
{[398.320]}\end{array}$ & $\begin{array}{c}2327.388 * * * \\
(362.908) \\
{[493.808]}\end{array}$ \\
\hline $\begin{array}{l}\text { First marriage } \times \text { divorce } \\
\text { probability }\end{array}$ & $\begin{array}{c}4715.265^{* *} \\
(868.814) \\
{[2389.004]}\end{array}$ & $\begin{array}{c}5549.014 * * \\
(1033.088) \\
{[2226.549]}\end{array}$ & $\begin{array}{l}-2337.963 \\
(1599.488) \\
{[2521.332]}\end{array}$ & $\begin{array}{l}-2207.696 \\
(1670.289) \\
{[3353.317]}\end{array}$ \\
\hline $\begin{array}{l}\text { Divorced } \times \text { remarriage } \\
\text { probability }\end{array}$ & $\begin{array}{c}800.133 \\
(412.886) \\
{[891.338]}\end{array}$ & $\begin{array}{c}1007.502 \\
(485.436) \\
{[1122.255]}\end{array}$ & $\begin{array}{c}460.906 \\
(664.842) \\
{[1643.534]}\end{array}$ & $\begin{array}{c}521.291 * * * \\
(694.478) \\
{[1394.518]}\end{array}$ \\
\hline $\begin{array}{l}\text { Subsequent marriage } \times \\
\text { divorce probability }\end{array}$ & $\begin{array}{c}-12549.440 \\
(9531.438) \\
{\left[7.05 \times 10^{6}\right]}\end{array}$ & $\begin{array}{l}-16737.690 \\
(11553.330) \\
{\left[4.48 \times 10^{5}\right]}\end{array}$ & $\begin{array}{c}7.18 \times 10^{6} \\
\left(5.13 \times 10^{6}\right) \\
{\left[5.67 \times 10^{11}\right]}\end{array}$ & $\begin{array}{c}7.12 \times 10^{6} \\
\left(5.53 \times 10^{6}\right) \\
{\left[1.10 \times 10^{9}\right]}\end{array}$ \\
\hline $\begin{array}{l}\text { (Pseudo) R-squared } \\
\text { Number of observations }\end{array}$ & $\begin{array}{c}0.208 \\
25,552\end{array}$ & $\begin{array}{c}0.017 \\
25,552\end{array}$ & $\begin{array}{c}0.151 \\
22,851\end{array}$ & $\begin{array}{c}0.011 \\
22,851\end{array}$ \\
\hline
\end{tabular}

Notes: Controls also include own and spouse highest grade completed, age difference between spouses, attitude to gender roles, number of children and child under 6, all interacted with marital status, plus age, age squared, black non-Hispanic, Hispanic, attended school, AFQT score, poor health, foreign born, 3 region dummies, urban, local unemployment rate and marital status dummies. Standard errors are presented in parentheses and bootstrapped standard errors in brackets. *, ** and $* * *$ denote significance at the $10 \%, 5 \%$ and $1 \%$ level, respectively, and refer to the bootstrap distribution where it is reported. 
Ordinary least squares estimates are presented in the first and third columns of Table 7 and tobit estimates are reported in the second and fourth columns. Bootstrapped standard errors are computed for the marital transition probability variables, to correct for prediction error in the first-stage hazard estimates. ${ }^{23}$ The wage and non-wage income elasticities are generally as expected. Women have higher wage elasticities than men in the same marital state and the elasticities for married men are actually negative. The hours worked by a married woman are more responsive to her spouse's wage rate than is the case for a married man. Although unreported, the coefficients on the gender roles attitude variables indicate that conservative women tend to work less than other women in all marital states, however conservative men also have slightly lower hours before and during first marriage, compared to other men.

Consistent with the predictions of the theory, higher probabilities of divorce are found to increase the hours worked by women in their first marriage, but to decrease the hours worked by men, although the latter relationship is statistically insignificant. Higher probabilities of first marriage are associated with more work hours among both men and women. The latter result is somewhat puzzling. One possible explanation is that a woman's marginal utility with respect to her hours is not constant over the life-cycle but rather is higher when divorced than when never married. The transition probabilities for those who have been divorced at least once are insignificant. As mentioned above, this may be because there are relatively few observations in divorced or remarried states or because after experiencing one divorce, people become less responsive to further changes in marital transition probabilities.

Unlike all previous studies, since I have a full panel for all individuals over the sample period, as they move between marital states, I can also employ panel data models. The first and third columns of Table 8 report the results of applying a fixed effects, or within, estimator to Equations 51 and 52, which controls for all unobserved timeinvariant determinants of labour supply. The marriage probability continues to have a

\footnotetext{
${ }^{23}$ As Johnson and Skinner (1986) noted, since individuals do not know whether they will change marital status in the following year at the time they make their labour supply decisions, the regular standard errors are only biased to the extent that the person's subjective probability explains more than the predicted hazard rate.
} 
Table 8

Within and between estimates of labour supply equations using estimated marriage and divorce hazard rates

\begin{tabular}{|l|c|c|c|c|}
\hline Variable & $\begin{array}{c}\text { (i) } \\
\text { Within } \\
\text { Females }\end{array}$ & $\begin{array}{c}\text { (ii) } \\
\text { Between } \\
\text { Females }\end{array}$ & $\begin{array}{c}\text { (iii) } \\
\text { Within } \\
\text { Males }\end{array}$ & $\begin{array}{c}\text { (iv) } \\
\text { Between } \\
\text { Males }\end{array}$ \\
\hline Never married $\times$ & 647.993 & $4393.990^{* * *}$ & $2114.120^{* * *}$ & $2461.066^{* * *}$ \\
marriage probability & $(458.777)$ & $(1062.648)$ & $(389.467)$ & $(939.086)$ \\
& {$[476.179]$} & {$[844.922]$} & {$[490.4969]$} & {$[1035.315]$} \\
First marriage $\times$ divorce & 2272.232 & $7293.940 * * *$ & 3573.985 & -3578.060 \\
probability & $(1030.905)$ & $(2134.298)$ & $(2335.473)$ & $(3538.877)$ \\
& {$[1797.585]$} & {$[2549.522]$} & {$[2342.904]$} & {$[2680.563]$} \\
Divorced $\times$ remarriage & 401.439 & 432.944 & 839.556 & 1850.282 \\
probability & $(459.915)$ & $(844.118)$ & $(663.519)$ & $(1445.243)$ \\
& {$[959.295]$} & {$[1174.655]$} & {$[1452.954]$} & {$[2774.321]$} \\
Subsequent marriage $\times$ & -20496.950 & -32659.990 & $1.01 \times 10^{7}$ & $-1.90 \times 10^{6}$ \\
divorce probability & $(12649.300)$ & $(16047.020)$ & $\left(6.17 \times 10^{6}\right)$ & $\left(9.01 \times 10^{6}\right)$ \\
& {$\left[1.43 \times 10^{6}\right]$} & {$\left[3.52 \times 10^{6}\right]$} & {$\left[3.54 \times 10^{11}\right]$} & {$\left[2.59 \times 10^{11}\right]$} \\
\hline R-squared & 0.534 & 0.383 & 0.480 & 0.286 \\
Number of observations & 25,552 & 25,552 & 22,851 & 23,963 \\
\hline
\end{tabular}

Notes: Controls also include own and spouse log wage, non-wage income, own and spouse highest grade completed, age difference between spouses, attitude to gender roles, number of children and child under 6, all interacted with marital status, plus age, age squared, black non-Hispanic, Hispanic, attended school, AFQT score, poor health, foreign born, 3 region dummies, urban, local unemployment rate and marital status dummies.

Standard errors are presented in parentheses and bootstrapped standard errors in brackets. *, ** and $* * *$ denote significance at the $10 \%, 5 \%$ and $1 \%$ level, respectively, and refer to the bootstrap distribution where it is reported.

positive effect on hours for both sexes, as does the divorce probability for women. ${ }^{24}$ These estimates imply that married women allocate labour supply optimally over their lifetimes in response to changes in probability of marital dissolution. The second and fourth columns of Table 8 give the results from the between estimator, whereby the observations are averaged over all periods for each individual. There is evidence that women from high divorce risk groups work more over the entire duration of their marriages, regardless of the specific danger of their own relationship ending. This casts doubt on the approach of Johnson and Skinner (1988), who analysed the reasons behind labour supply increases by women after divorce by comparing hours two and three years prior to separation and one and two years afterwards.

The identification of the coefficients on the marriage and divorce probabilities in Tables 7 and 8 depends crucially on the exclusion of variables from the labour supply

\footnotetext{
${ }^{24}$ A Hausman test rejected the hypothesis that a random effects estimator is consistent.
} 
Table 9

Estimates of labour supply equations using marital happiness variable

\begin{tabular}{|l|c|c|c|c|}
\hline Variable & $\begin{array}{c}\text { (i) } \\
\text { Tobit } \\
\text { Females }\end{array}$ & $\begin{array}{c}\text { (ii) } \\
\text { Within } \\
\text { Females }\end{array}$ & $\begin{array}{c}\text { (iii) } \\
\text { Tobit with lags } \\
\text { Females }\end{array}$ & $\begin{array}{c}\text { Wiv) } \\
\text { Females }\end{array}$ \\
\hline First marriage $\times$ happy & $-56.811^{*}$ & -37.418 & $-92.178^{* * *}$ & $-120.964^{* * *}$ \\
with marriage & $(30.459)$ & $(28.007)$ & $(31.475)$ & $(28.464)$ \\
First marriage $\times$ unhappy & 120.970 & 69.710 & $191.032^{* *}$ & 70.554 \\
with marriage & $(81.380)$ & $(63.801)$ & $(85.995)$ & $(68.040)$ \\
\hline (Pseudo) R-squared & 0.012 & 0.468 & 0.012 & 0.487 \\
Number of observations & 21,946 & 21,946 & 18,423 & 18,423 \\
\hline
\end{tabular}

Notes: Controls also include own and spouse log wage, non-wage income, own and spouse highest grade completed, age difference between spouses, attitude to gender roles, number of children and child under 6, all interacted with marital status, plus age, age squared, black non-Hispanic, Hispanic, attended school, AFQT score, poor health, foreign born, 3 region dummies, urban, local unemployment rate and marital status dummies.

Standard errors are presented in parentheses. *, ** and *** denote significance at the $10 \%, 5 \%$ and $1 \%$ level, respectively.

equation that are relevant to the likelihood of marriage or divorce occurring. ${ }^{25}$ Given the absence of any clearly exogenous shocks to the marriage and divorce equations, there is a risk that some of these variables have an independent effect on labour supply. For example, Heineck (2004) found that strongly religious married women tend to work less than other married women in Germany. An alternative approach that has not been considered previously is to rely on a respondent's own evaluation of the state of his/her marriage. This has two advantages over the use of predicted divorce. Firstly, it allows the identification of individuals who anticipate divorces that never transpire and vice versa. Secondly, if satisfaction with marriage is evaluated in the same period as hours, it circumvents the problem of reverse causality encountered when using divorce in the future as a measure of divorce risk. However, estimates may still be susceptible to endogeneity bias if marital satisfaction and work hours are jointly determined by unobserved variables.

The NLSY includes questions on whether respondents were "very happy", "fairly happy" or "not too happy" with their current marriage. Unfortunately, these were only asked of women in 1992 and 1994 onwards. Table 9 presents the results of estimating Equation 51 for these years only. The measures of divorce risk are the interaction of first

\footnotetext{
${ }^{25}$ Technically, the non-linear nature of Cox proportional hazard model is sufficient to identify the labour supply equation.
} 
Table 10

Estimates of labour supply equations including the wage ratio

\begin{tabular}{|c|c|c|c|c|}
\hline Variable & $\begin{array}{c}\text { (i) } \\
\text { OLS } \\
\text { Females }\end{array}$ & $\begin{array}{c}\text { (ii) } \\
\text { Tobit } \\
\text { Females }\end{array}$ & $\begin{array}{l}\text { (iii) } \\
\text { OLS } \\
\text { Males }\end{array}$ & $\begin{array}{c}\text { (iv) } \\
\text { Tobit } \\
\text { Males }\end{array}$ \\
\hline $\begin{array}{l}\text { Never married } \times \\
\text { marriage probability }\end{array}$ & $\begin{array}{c}\text { 3866.611*** } \\
(406.379) \\
{[507.181]}\end{array}$ & $\begin{array}{c}4371.149 * * * \\
(481.052) \\
{[563.448]}\end{array}$ & $\begin{array}{c}2202.906^{* * *} \\
(347.209) \\
{[590.796]}\end{array}$ & $\begin{array}{c}2358.891 * * * \\
(362.865) \\
{[561.397]}\end{array}$ \\
\hline $\begin{array}{l}\text { First marriage } \times \text { divorce } \\
\text { probability }\end{array}$ & $\begin{array}{c}4120.986^{* *} \\
(935.148) \\
{[2033.541]}\end{array}$ & $\begin{array}{l}4774.081^{* *} \\
(1107.809) \\
{[1955.054]}\end{array}$ & $\begin{array}{l}-3394.193 \\
(1618.850) \\
{[4574.468]}\end{array}$ & $\begin{array}{l}-3194.028 \\
(1689.947) \\
{[4221.708]}\end{array}$ \\
\hline $\begin{array}{l}\text { Divorced } \times \text { remarriage } \\
\text { probability }\end{array}$ & $\begin{array}{c}805.874 \\
(412.839) \\
{[1016.250]}\end{array}$ & $\begin{array}{c}1016.107 \\
(485.367) \\
{[1321.819]}\end{array}$ & $\begin{array}{c}509.345 \\
(664.684) \\
{[2015.533]}\end{array}$ & $\begin{array}{c}566.841 \\
(694.288) \\
{[1377.602]}\end{array}$ \\
\hline $\begin{array}{l}\text { Subsequent marriage } \times \\
\text { divorce probability }\end{array}$ & $\begin{array}{c}15266.870 \\
(13720.240) \\
{\left[1.32 \times 10^{6}\right]}\end{array}$ & $\begin{array}{c}8626.519 \\
(16647.000) \\
{\left[4.31 \times 10^{5}\right]}\end{array}$ & $\begin{array}{l}1.47 \times 10^{7} \\
\left(6.63 \times 10^{6}\right) \\
{\left[2.66 \times 10^{11}\right]}\end{array}$ & $\begin{array}{l}1.52 \times 10^{7} \\
\left(6.91 \times 10^{6}\right) \\
{\left[1.90 \times 10^{9}\right]}\end{array}$ \\
\hline $\begin{array}{l}\text { First marriage } \times \text { divorce } \\
\text { probability } \times \text { log wage } \\
\text { ratio }\end{array}$ & $\begin{array}{c}-1634.365 \\
(866.219) \\
{[1725.132]}\end{array}$ & $\begin{array}{l}-2155.463 \\
(1039.357) \\
{[2072.967]}\end{array}$ & $\begin{array}{c}7432.218 * * * \\
(1798.833) \\
{[2778.138]}\end{array}$ & $\begin{array}{c}\text { 7014.738*** } \\
(1881.019) \\
{[2770711]}\end{array}$ \\
\hline $\begin{array}{l}\text { Subsequent marriage } \times \\
\text { divorce probability } \times \log \\
\text { wage ratio }\end{array}$ & $\begin{array}{c}23122.350 * * \\
(8206.426) \\
{[9497.462]} \\
\end{array}$ & $\begin{array}{c}20495.020^{*} \\
(9748.456) \\
{[11915.820]} \\
\end{array}$ & $\begin{array}{l}-2.05 \times 10^{7} \\
\left(1.16 \times 10^{7}\right) \\
{\left[1.91 \times 10^{7}\right]} \\
\end{array}$ & $\begin{array}{l}-2.24 \times 10^{7} \\
\left(1.22 \times 10^{7}\right) \\
{\left[1.88 \times 10^{7}\right]} \\
\end{array}$ \\
\hline $\begin{array}{l}\text { (Pseudo) R-squared } \\
\text { Number of observations } \\
\end{array}$ & $\begin{array}{c}0.209 \\
25,552 \\
\end{array}$ & $\begin{array}{c}0.017 \\
25,552 \\
\end{array}$ & $\begin{array}{c}0.152 \\
22,851 \\
\end{array}$ & $\begin{array}{c}0.011 \\
22,851 \\
\end{array}$ \\
\hline
\end{tabular}

Notes: Controls also include own and spouse log wage, non-wage income, own and spouse highest grade completed, age difference between spouses, attitude to gender roles, number of children and child under 6, all interacted with marital status, plus age, age squared, black non-Hispanic, Hispanic, attended school, AFQT score, poor health, foreign born, 3 region dummies, urban, local unemployment rate and marital status dummies.

Standard errors are presented in parentheses and bootstrapped standard errors in brackets. *, ** and $* * *$ denote significance at the $10 \%, 5 \%$ and $1 \%$ level, respectively, and refer to the bootstrap distribution where it is reported.

marriage with a dummy for those who responded that they were "very happy" with their marriage and those who responded that they were "not too happy". The first two columns of Table 9 reveal that those who are unhappy with their marriage are found to work longer hours that the baseline group, whereas those who are very happy work less, however these results are only marginally significant. Once problem is that marital satisfaction is measured as of the interview date, whereas hours of work pertain to the previous calendar year, meaning that endogeneity may still be a problem. A simple solution is to use the level of marital satisfaction from two years earlier, as this should be exogenous to the current labour supply decision. The third column of Table 9 shows that this yields highly significant results. Those who are very happy with their marriage work 92 hours fewer than the comparison group; those who are unhappy work 191 hours more. 
The former result remains when individual effects are included, as seen in the final column.

Finally, it should be remembered that the labour supply equations 51 and 52 are linear approximations to the first order conditions that arise from the theoretical model. With higher order approximations, one would expect to find interactions of the marital transition probabilities with own and spouse wages. To examine this possibility, I repeat the main specifications from Table 7, adding the log ratio of a married woman's wage to her husband's wage as a regressor. As reported in Table 10, this ratio has a significant coefficient for women and a positive coefficient for men, although the former is not significant under the bootstrap distribution. These results imply that as a woman's wage increases towards parity with her husband, the risk of divorce has an increasingly small effect on her hours of work. They also suggest that divorce risk can play an important role in the work decisions of those men who earn lower wages than their wives. This finding supports the conclusions of the model presented in Section 3 insofar as it indicates that the differences in the labour supply-divorce risk relationship hinge solely on the assumption that men earn more than women, rather than any specific gender roles within the household.

\section{Conclusion}

For the first time, this paper has attempted to provide a theoretical framework to explain the relationship between the probability of a person changing marital state and the amount of labour he/she supplies. Married couples interact in a non-cooperative fashion. Working longer hours in the labour market increases the wage a person will receive in the future, meaning that some married individuals may want to insure against the risk of divorce by devoting more time to paid work than they would otherwise do. The model predicts that labour supply will be positively related to the probability of divorce for a person who earns a lower wage than his/her spouse and vice versa.

I tested the predictions of this model, drawing on longitudinal data from the NLSY 1979. Marriage and divorce probabilities were estimated using Cox proportional hazard models. These were then used as explanatory variables in labour supply regressions. As expected, married women work more hours when the probability they will divorce is 
higher. However, this effect only seems to hold for first marriages. Never-married men and women both work more if they have a greater chance of marriage. This last finding is intriguing and will be analysed further in future work. The link between marital transition probabilities and hours is observed both over a person's life-cycle and across individuals and persists when arguably exogenous measures of divorce risk are used. There is also some evidence that the effect of divorce risk on hours is stronger for women who earn significantly less than their husbands.

Additional research will also explicitly consider whether work hours influence divorce probabilities, i.e. whether there is an additional causal effect in the reverse direction. Gray (1995) and Sen (2002) found no evidence of this using NLSY 1979 data, however Johnson (2004) provided evidence suggesting that the work hours of women in the Survey of Income and Program Participation have an independent effect on the likelihood of divorce. ${ }^{26}$

Finally, future work will focus on the predictions of the theory, comparing the Nash equilibrium results that are generated for married couples with the Pareto efficient outcomes and determining whether these might be achieved within a cooperative bargaining framework.

\section{References}

Ahituv, A. and Lerman, R.I. (2005). How do marital status, wage rates, and work commitment interact? IZA Discussion Paper No. 1688, Bonn.

Allen, D.W. (1992). Marriage and divorce: Comment. American Economic Review, 82, 679-685.

Austen, S. (2004). Labour supply and the risk of divorce: An analysis of Australian data. Australian Economic Review, 37, 153-165.

Balakrishnan, T.R., Rao, K.V., Lapierre-Adamcyk, E. and Krotki, K.J. (1987). A hazard model analysis of the covariates of marital dissolution in Canada. Demography, 24, 395-406.

Bedard, K. and Deschênes, O. (2005). Sex preferences, marital dissolution, and the economic status of women. Journal of Human Resources, 40, 411-434.

Blau, F.D. and Kahn, L.M. (2005). Changes in the labor supply behavior of married women: 1980-2000. Working Paper 11230, National Bureau of Economic Research, Cambridge, MA.

\footnotetext{
${ }^{26}$ Johnson's conclusion was based on the assumption that married people are less likely to adjust their work hours in anticipation of separation rather than actual divorce.
} 
Blackburn, M. and Korenman, S. (1994). The declining marital status earnings differential. Journal of Population Economics, 7, 249-270.

Bremmer, D. and Kesselring, R. (2004). Divorce and female labor force participation: Evidence from timeseries data and cointegration. Atlantic Economic Journal, 32, 174-189.

Castro Martin, T. and Bumpass, L.L. (1989). Recent trends in marital disruption. Demography, 26, 37-51.

Chiappori, P.A., Fortin, B. and Lacroix, G. (2002). Marriage market, divorce legislation, and household labor supply. Journal of Political Economy, 110, 37-72.

Chun, H. and Lee, I. (2001). Why do married men earn more: Productivity or marriage selection? Economic Inquiry, 39, 307-319.

Clarke, S.C. (1995). Advance report of final divorce statistics, 1989 and 1990. Monthly vital statistics report, vol. 43, no. 9, suppl. Hyattsville, MD: National Center for Health Statistics.

Cohen, P.N. (2002). Cohabitation and the declining marriage premium for men. Work and Occupations, 29, 34-363.

Cornwell, C. and Rupert, P. (1997). Unobservable individual effects, marriage and the earnings of young men. Economic Inquiry, 285-294.

Daniel, K. (1992). Does marriage make men more productive? Discussion Paper No. 92-2, National Opinion Research Center, University of Chicago.

Friedberg, L. (1998). Did unilateral divorce raise divorce rates? Evidence from panel data. American Economic Review, 88, 608-627.

Gray, J.S. (1995). The causality between employment and divorce. Family Economics and Resources Management Biennial, 1, 171-176.

Gray, J.S. (1997). The fall in men's return to marriage: Declining productivity effects or changing selection? Journal of Human Resources, 32, 481-504.

Gray, J.S. (1998). Divorce law changes, household bargaining and married women's labor supply. American Economic Review, 88, 628-642.

Greene, W.H. and Quester, A.O. (1982). Divorce risk and wives' labor supply behavior. Social Science Quarterly, 63, 16-27.

Haurin, D.R. (1989). Women's labor force market reactions to family disruptions. Review of Economics and Statistics, 71, 54-61.

Heineck, G. (2004). Does religion influence the labor supply of married women in Germany? Journal of Socio-Economics, 33, 307-328.

Hersch, J. and Stratton, L.S. (2000). Household specialization and the male marriage wage premium. Industrial and Labor Relations Review, 54, 78-94.

Iyigun, M. (2005). Bargaining and specialization in marriage. Discussion Paper No. 1744, Forschungsinstitut zur Zukunft der Arbeit (IZA), Bonn.

Jacobsen, J. and Rayack, W.L. (1996). Do men whose wives work really earn less? American Economic Review, 86, 268-273. 
Johnson, J.H., IV (2004). Do long work hours contribute to divorce? Topics in Economic Analysis \& Policy, 4, Article 24.

Johnson, W.R. and Skinner, J. (1986). Labor supply and marital separation. American Economic Review, 76, 455-469.

Johnson, W.R. and Skinner, J. (1988). Accounting for changes in the labor supply of recently divorced women. Journal of Human Resources, 23, 417-436.

Koo, H.P., Suchindran, C.M. and Griffith, J.D. (1984). The effects of children on divorce and re-marriage: A multivariate analysis of life table probabilities. Population Studies, 38, 451-471.

Korenman, S. and Neumark, D. (1991). Does marriage really make men more productive? Journal of Human Resources, 26, 282-307.

Loh, E.S. (1996). Productivity differences and the marriage wage premium for white males. Journal of Human Resources, 31, 566-589.

Lundberg, S. and Pollak, R.A. (1993). Separate spheres bargaining and the marriage market. Journal of Political Economy, 101, 988-1010.

Lundberg, S. and Pollak. R.A. (1996). Bargaining and distribution in marriage. Journal of Economic Perspectives, 10, 139-158.

Michael, R.T. and Brandon Tuma, N. (1985). Entry into marriage and parenthood by young men and women: The influence of family background. Demography, 22, 515-544.

Millimet, D.L., Sarkar, D. and Maasoumi, E. (2004). A distributional analysis of the return to marriage. Unpublished manuscript, Southern Methodist University.

Montalto, C.P. and Gerner, J.L. (1998). The effect of expected changes in marital status on labor supply decisions of women and men. Journal of Divorce and Remarriage, 28, 25-51.

Nakosteen, R.A. and Zimmer, M.A. (1987). Marital status and earnings of young men: A model of endogenous selection. Journal of Human Resources, 22, 248-268.

Orcutt, G., Caldwell, S. and Wertheimer, R., II (1976). Policy exploitation through microanalytic simulation. Washington, D.C.: Urban Institute.

Parkman, A.M. (1992). Unilateral divorce and the labor-force participation rate of married women, revisited. American Economic Review, 82, 671-678.

Peters, H.E. (1986). Marriage and divorce: Informational constraints and private contracting. American Economic Review, 76, 437-454.

Seitz, S.N. (1999). Labor supply, divorce and remarriage. Unpublished manuscript, University of Western Ontario.

Sen, B. (2000). How important is anticipation of divorce in married women's labor supply decisions? An intercohort comparison using NLS data. Economics Letters, 67, 209-216.

Sen, B. (2002). Does married women's market work affect marital stability adversely? An intercohort analysis using NLS data. Review of Social Economy, 60, 71-92.

Shapiro, D. and Shaw, L. (1983). Growth in the labor force attachment of married women: Accounting for changes in the 1970's. Southern Economic Journal, 50, 461-473. 
United States Census Bureau (2003). Statistical abstract of the United States: The national data book. Washington, DC: United States Census Bureau.

Van der Klaauw, W. (1996). Female labour supply and marital status decisions: A life-cycle model. Review of Economic Studies, 63, 199-235.

Wolfers, J. (2006). Did unilateral divorce raise divorce rates? A reconciliation and new results. American Economic Review, forthcoming. 


\section{Appendix 1}

I wish to prove that if $\bar{w}_{t}>w_{t}+2 R_{t}$ and $\delta<1$ then $v_{t+1}^{U}>v_{t+1}^{M}$ and $\bar{v}_{t+1}^{M}>\bar{v}_{t+1}^{U}, \forall t$, however, first I need to prove that $\bar{\phi}_{t}>\phi_{t}$ and $\bar{\varphi}_{t}>\varphi_{t}, \forall t<T$. In cases, my approach is to use proof by induction.

a. Proof that $\bar{\phi}_{t}>\phi_{t}$ and $\bar{\varphi}_{t}>\varphi_{t}, \forall t<T$

i. Proof that $\bar{\phi}_{T-1}>\phi_{T-1}$ and $\bar{\varphi}_{T-1}>\varphi_{T-1}$

$$
\begin{array}{r}
\bar{\varphi}_{T-1}-\varphi_{T-1}=\beta \theta\left(\eta _ { T } \frac { \lambda \overline { \lambda } \delta } { \lambda + \overline { \lambda } - 1 } \left(\frac{1}{\lambda \hat{w}}\left(\frac{1-\bar{\lambda}}{\delta} \hat{\bar{w}}+\frac{2 \bar{\lambda}-1}{\bar{\lambda}} \hat{R}\right)-\frac{1}{\bar{\lambda} \hat{\bar{w}}}\left(\frac{1-\lambda}{\delta} \hat{w}+\frac{2 \lambda-1}{\lambda} \hat{R}\right)\right.\right. \\
\left.\left.+\frac{(1-\bar{\lambda}) \hat{\bar{w}}}{\delta \lambda \hat{w}}-\frac{(1-\lambda) \hat{w}}{\delta \bar{\lambda} \hat{\bar{w}}}\right)+\left(1-\eta_{T}\right) \delta \hat{R}\left(\frac{1}{\hat{w}}-\frac{1}{\hat{\bar{w}}}\right)\right) ; \\
=\beta \theta\left(\eta_{T} \frac{\lambda \bar{\lambda} \delta}{\lambda+\bar{\lambda}-1}\left(\frac{2(1-\bar{\lambda}) \hat{\bar{w}}}{\lambda \delta \hat{w}}-\frac{2(1-\lambda) \hat{w}}{\bar{\lambda} \delta \hat{\bar{w}}}+\frac{\hat{R}}{\lambda \bar{\lambda}}\left(\frac{2 \bar{\lambda}-1}{\hat{w}}-\frac{2 \lambda-1}{\hat{\bar{w}}}\right)\right)\right. \\
\left.+\left(1-\eta_{T}\right) \delta \hat{R}\left(\frac{1}{\hat{w}}-\frac{1}{\hat{\bar{w}}}\right)\right) ;
\end{array}
$$

We know:

$$
\frac{1}{\hat{w}}>\frac{1}{\hat{\hat{w}}}, \text { since } \bar{w}_{t}>w_{t},
$$

and:

$$
\begin{aligned}
& \frac{2 \bar{\lambda}(1-\bar{\lambda}) \hat{\bar{w}}}{\hat{w}}-\frac{2 \lambda(1-\lambda) \hat{w}}{\hat{\bar{w}}}+\delta \hat{R}\left(\frac{2 \bar{\lambda}-1}{\hat{w}}-\frac{2 \lambda-1}{\hat{\bar{w}}}\right)>\frac{2 \bar{\lambda}(1-\bar{\lambda}) \hat{\bar{w}}}{\hat{w}}-\frac{2 \lambda(1-\lambda) \hat{w}}{\hat{\bar{w}}} \\
& +\frac{\delta(\hat{\bar{w}}-\hat{w})}{\hat{\bar{w}}}(\bar{\lambda}-\lambda)
\end{aligned}
$$

$>0$, as above.

Hence:

$$
\bar{\varphi}_{T-1}-\varphi_{T-1}>0 \text {. }
$$

Similarly, $\bar{\phi}_{T-1}>\phi_{T-1}$.

ii. Proof that $\bar{\phi}_{t+1}>\phi_{t+1}$ and $\bar{\varphi}_{t+1}>\varphi_{t+1}$ imply that $\bar{\phi}_{t}>\phi_{t}$ and $\bar{\varphi}_{t}>\varphi_{t}$ 


$$
\begin{aligned}
& \bar{\varphi}_{t}-\varphi_{t}=\beta \theta\left(\eta _ { t } \frac { \delta } { \lambda + \overline { \lambda } - 1 } \left(\frac{2 \bar{\lambda}(1-\bar{\lambda}) \hat{\bar{w}}}{\left(\delta-\bar{\phi}_{t+1}\right) \hat{w}}-\frac{2 \lambda(1-\lambda) \hat{w}}{\left(\delta-\phi_{t+1}\right) \hat{\bar{w}}}+\hat{R}\left(\frac{2 \bar{\lambda}-1}{\hat{w}}-\frac{2 \lambda-1}{\hat{\bar{w}}}\right)\right.\right. \\
& \left.+\frac{1-\rho}{\theta} \lambda \bar{\lambda}\left(\bar{\phi}_{t+1}-\phi_{t+1}\right)\right)+\left(1-\eta_{t}\right)\left(\delta \hat{R}\left(\frac{1}{\hat{w}}-\frac{1}{\hat{\hat{w}}}\right)+\frac{1-\rho}{\theta}\left(\bar{\varphi}_{t+1}-\varphi_{t+1}\right)\right) \\
& >\beta \theta\left(\eta _ { t } \frac { \delta } { \lambda + \overline { \lambda } - 1 } \left(\frac{2 \bar{\lambda}(1-\bar{\lambda}) \hat{\bar{w}}}{\left(\delta-\bar{\phi}_{t+1}\right) \hat{w}}-\frac{2 \lambda(1-\lambda) \hat{w}}{\left(\delta-\phi_{t+1}\right) \hat{\bar{w}}}+\frac{\hat{\bar{w}}-\hat{w}}{\hat{\bar{w}}}(\bar{\lambda}-\lambda)\right.\right. \\
& \left.+\frac{1-\rho}{\theta} \lambda \bar{\lambda}\left(\bar{\phi}_{t+1}-\phi_{t+1}\right)\right)+\left(1-\eta_{t}\right)\left(\delta \hat{R}\left(\frac{1}{\hat{w}}-\frac{1}{\hat{\bar{w}}}\right)+\frac{1-\rho}{\theta}\left(\bar{\varphi}_{t+1}-\varphi_{t+1}\right)\right) ; \\
& >\beta \theta\left(\eta_{t} \frac{\delta}{\lambda+\bar{\lambda}-1}\left(\frac{2}{\delta-\phi_{t+1}}\left(\frac{\bar{\lambda}(1-\bar{\lambda}) \hat{\bar{w}}}{\hat{w}}-\frac{\lambda(1-\lambda) \hat{w}}{\hat{\bar{w}}}\right)+\frac{\hat{\bar{w}}-\hat{w}}{\hat{\bar{w}}}(\bar{\lambda}-\lambda)\right)\right. \\
& +\left(1-\eta_{t}\right) \delta \hat{R}\left(\frac{1}{\hat{w}}-\frac{1}{\hat{\hat{w}}}\right) \text {, since } \bar{\phi}_{t+1}>\phi_{t+1} \text { and } \bar{\varphi}_{t+1}>\varphi_{t+1} ; \\
& >\beta \theta \eta_{t} \frac{\delta}{\lambda+\bar{\lambda}-1} \frac{2}{\delta-\phi_{t+1}}(\bar{\lambda}(1-\bar{\lambda})-\lambda(1-\lambda)) \text {, since increasing in } \frac{\bar{w}_{t}}{w_{t}} ; \\
& >0 \text {, since } \lambda>\bar{\lambda}, \lambda>\frac{1}{2} \text { and } \bar{\lambda}>\frac{1}{2} \text {. }
\end{aligned}
$$

Similarly, $\bar{\phi}_{t}>\phi_{t}$ if $\bar{\varphi}_{t+1}>\varphi_{t+1}$ and $\bar{\phi}_{t+1}>\phi_{t+1}$.

b. Proof that $v_{t+1}^{U}>v_{t+1}^{M}$ and $\bar{v}_{t+1}^{M}>\bar{v}_{t+1}^{U}, \forall t$

i. Proof that $v_{T}^{U}>v_{T}^{M}$ and $\bar{v}_{T}^{M}>\bar{v}_{T}^{U}$

$$
\bar{v}_{T}^{M}-\bar{v}_{T}^{U}=\delta \frac{\hat{\bar{R}}}{\overline{\hat{w}}}-\frac{\lambda \bar{\lambda} \delta}{\lambda+\bar{\lambda}-1}\left(\frac{1}{\bar{\lambda} \hat{\hat{w}}}\left(\frac{1-\lambda}{\delta} \hat{w}+\frac{2 \lambda-1}{\lambda} \hat{\bar{R}}\right)-\frac{1}{\delta} \frac{(1-\bar{\lambda}) \hat{\bar{w}}}{\lambda \hat{w}}\right) \text {, from Equations }
$$

42 and 43;

$$
\begin{aligned}
& =\frac{1}{\lambda+\bar{\lambda}-1}\left(\bar{\lambda}(1-\bar{\lambda}) \frac{\hat{\bar{w}}}{\hat{w}}-\lambda(1-\lambda) \frac{\hat{w}}{\hat{\hat{w}}}+(\bar{\lambda}-\lambda) \frac{\hat{\bar{R}} \delta}{\hat{\bar{w}}}\right) ; \\
& >\frac{1}{\lambda+\bar{\lambda}-1}\left(\bar{\lambda}(1-\bar{\lambda}) \frac{\hat{\bar{w}}}{\hat{w}}-\lambda(1-\lambda) \frac{\hat{w}}{\hat{\hat{w}}}+(\bar{\lambda}-\lambda) \delta \frac{\hat{\bar{w}}-\hat{w}}{2 \hat{\bar{w}}}\right), \text { since } \lambda>\bar{\lambda} \text { and }
\end{aligned}
$$

$\bar{w}_{t}>w_{t}+2 R_{t}$

$$
>\frac{1}{\lambda+\bar{\lambda}-1}(\bar{\lambda}(1-\bar{\lambda})-\lambda(1-\lambda)), \text { since increasing in } \frac{\bar{w}_{t}}{w_{t}} ;
$$




$$
\begin{aligned}
>0, \text { since } \lambda>\bar{\lambda}, \lambda>\frac{1}{2} \text { and } \bar{\lambda}>\frac{1}{2} . \\
v_{T}^{U}-v_{T}^{M}=\bar{v}_{T}^{M}-\bar{v}_{T}^{U}>0
\end{aligned}
$$

ii. Proof that $v_{t+1}^{U}>v_{t+1}^{M}$ and $\bar{v}_{t+1}^{M}>\bar{v}_{t+1}^{U}$ imply that $v_{t}^{U}>v_{t}^{M}$ and $\bar{v}_{t}^{M}>\bar{v}_{t}^{U}$

$$
\begin{aligned}
& \bar{v}_{t+1}^{M}-\bar{v}_{t+1}^{U}=\frac{\delta}{\lambda+\bar{\lambda}-1}\left(\frac{\bar{\lambda}(1-\bar{\lambda})}{\delta-\bar{\phi}_{t+1}} \frac{\hat{\bar{w}}}{\hat{w}}-\frac{\lambda(1-\lambda)}{\delta-\phi_{t+1}} \frac{\hat{w}}{\hat{\bar{w}}}+(\bar{\lambda}-\lambda) \frac{\hat{R}}{\hat{\bar{w}}}\right) \\
& +\frac{\beta(1-\rho)}{\theta}\left(1-\gamma_{t+1}-\eta_{t+1}\right)\left(\bar{v}_{t+2}^{M}-\bar{v}_{t+2}^{U}\right), \text { from Equations } 42 \text { and 43; } \\
& >\frac{\delta}{\lambda+\bar{\lambda}-1}\left(\frac{\bar{\lambda}(1-\bar{\lambda})}{\delta-\bar{\phi}_{t+1}} \frac{\hat{\bar{w}}}{\hat{w}}-\frac{\lambda(1-\lambda)}{\delta-\phi_{t+1}} \frac{\hat{w}}{\hat{\bar{w}}}+\frac{\bar{\lambda}-\lambda}{2} \frac{\hat{\bar{w}}-\hat{w}}{\hat{\bar{w}}}\right) \\
& +\frac{\beta(1-\rho)}{\theta}\left(1-\gamma_{t+1}-\eta_{t+1}\right)\left(\bar{v}_{t+2}^{M}-\bar{v}_{t+2}^{U}\right) ; \\
& >\frac{\delta}{\lambda+\bar{\lambda}-1}\left(\frac{1}{\delta-\phi_{t+1}}\left(\bar{\lambda}(1-\bar{\lambda}) \frac{\hat{\bar{w}}}{\hat{w}}-\lambda(1-\lambda) \frac{\hat{w}}{\hat{\bar{w}}}\right)+\frac{\bar{\lambda}-\lambda}{2} \frac{\hat{\bar{w}}-\hat{w}}{\hat{\bar{w}}}\right) \\
& +\frac{\beta(1-\rho)}{\theta}\left(1-\gamma_{t+1}-\eta_{t+1}\right)\left(\bar{v}_{t+2}^{M}-\bar{v}_{t+2}^{U}\right), \text { since } \bar{\phi}_{t}>\phi_{t} ; \\
& >\frac{\delta}{\lambda+\bar{\lambda}-1} \frac{1}{\delta-\phi_{t+1}}(\bar{\lambda}(1-\bar{\lambda})-\lambda(1-\lambda)) \\
& +\frac{\beta(1-\rho)}{\theta}\left(1-\gamma_{t+1}-\eta_{t+1}\right)\left(\bar{v}_{t+2}^{M}-\bar{v}_{t+2}^{U}\right), \text { since increasing in } \frac{\bar{w}_{t}}{w_{t}} ; \\
& >0 \text {, since } \lambda>\bar{\lambda}, \lambda>\frac{1}{2} \text { and } \bar{\lambda}>\frac{1}{2} \text { and } \bar{v}_{t+2}^{M}>\bar{v}_{t+2}^{U} \text {. } \\
& v_{t+1}^{U}-v_{t+1}^{M}=\frac{\delta}{\lambda+\bar{\lambda}-1}\left(\frac{\bar{\lambda}(1-\bar{\lambda})}{\delta-\bar{\phi}_{t+1}} \frac{\hat{w}}{\hat{w}}-\frac{\lambda(1-\lambda)}{\delta-\phi_{t+1}} \frac{\hat{w}}{\hat{\bar{w}}}+(\bar{\lambda}-\lambda) \frac{\hat{R}}{\hat{\bar{w}}}\right) \\
& +\frac{\beta(1-\rho)}{\theta}\left(1-\gamma_{t+1}-\eta_{t+1}\right)\left(v_{t+2}^{U}-v_{t+2}^{M}\right) ;
\end{aligned}
$$

$>0$, given the previous result. 


\section{Appendix 2}

Table A1

Coefficients from Cox proportional hazard model estimates for the probability of divorce

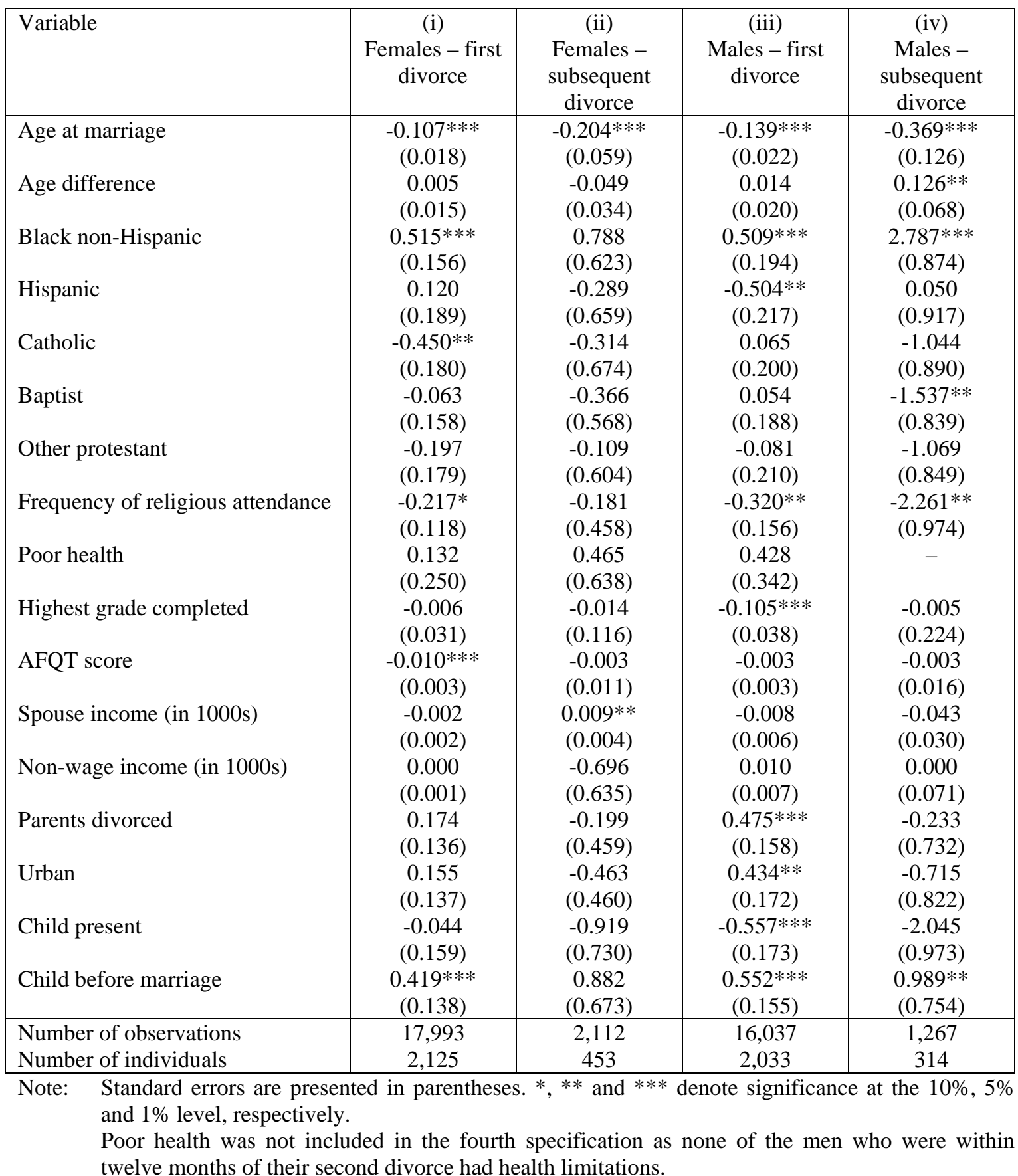


Table A2

Coefficients from Cox proportional hazard model estimates for the probability of marriage and remarriage

\begin{tabular}{|c|c|c|c|c|}
\hline Variable & $\begin{array}{c}\text { (i) } \\
\text { Females - first } \\
\text { marriage }\end{array}$ & $\begin{array}{c}\text { (ii) } \\
\text { Females - } \\
\text { subsequent } \\
\text { marriage }\end{array}$ & $\begin{array}{l}\text { (iii) } \\
\text { Males - first } \\
\text { marriage }\end{array}$ & $\begin{array}{c}\text { (iv) } \\
\text { Males - } \\
\text { subsequent } \\
\text { marriage }\end{array}$ \\
\hline Black non-Hispanic & $\begin{array}{c}-0.630 * * * \\
(0.068)\end{array}$ & $\begin{array}{c}-1.247 * * * \\
(0.247)\end{array}$ & $\begin{array}{c}-0.654 * * * \\
(0.068)\end{array}$ & $\begin{array}{c}-0.582 * * \\
(0.285)\end{array}$ \\
\hline Hispanic & $\begin{array}{l}-0.097 \\
(0.065)\end{array}$ & $\begin{array}{c}0.029 \\
(0.200)\end{array}$ & $\begin{array}{l}-0.039 \\
(0.066)\end{array}$ & $\begin{array}{c}0.294 \\
(0.292)\end{array}$ \\
\hline Catholic & $\begin{array}{l}-0.039 \\
(0.064)\end{array}$ & $\begin{array}{c}-0.527^{* *} \\
(0.209)\end{array}$ & $\begin{array}{c}-0.237 * * * \\
(0.063)\end{array}$ & $\begin{array}{c}-0.132 \\
(0.289)\end{array}$ \\
\hline Baptist & $\begin{array}{c}0.047 \\
(0.068)\end{array}$ & $\begin{array}{l}-0.017 \\
(0.212)\end{array}$ & $\begin{array}{l}-0.027 \\
(0.069)\end{array}$ & $\begin{array}{c}0.129 \\
(0.284)\end{array}$ \\
\hline Other protestant & $\begin{array}{l}-0.053 \\
(0.067)\end{array}$ & $\begin{array}{c}0.047 \\
(0.193)\end{array}$ & $\begin{array}{c}-0.143 * * \\
(0.067)\end{array}$ & $\begin{array}{c}0.188 \\
(0.308)\end{array}$ \\
\hline Frequency of religious attendance & $\begin{array}{c}0.126 * * * \\
(0.044)\end{array}$ & $\begin{array}{c}0.187 \\
(0.209)\end{array}$ & $\begin{array}{c}0.137 * * * \\
(0.048)\end{array}$ & $\begin{array}{c}0.264 \\
(0.204)\end{array}$ \\
\hline Poor health & $\begin{array}{l}-0.034 \\
(0.108)\end{array}$ & $\begin{array}{c}-0.675^{*} \\
(0.387)\end{array}$ & $\begin{array}{l}-0.078 \\
(0.123)\end{array}$ & $\begin{array}{c}0.027 \\
(0.424)\end{array}$ \\
\hline Highest grade completed & $\begin{array}{c}-0.071^{* * *} \\
(0.011)\end{array}$ & $\begin{array}{c}0.046 \\
(0.040)\end{array}$ & $\begin{array}{c}-0.048^{* * *} \\
(0.011)\end{array}$ & $\begin{array}{c}0.140 * * \\
(0.055)\end{array}$ \\
\hline AFQT score & $\begin{array}{c}0.001 \\
(0.001)\end{array}$ & $\begin{array}{l}-0.001 \\
(0.004)\end{array}$ & $\begin{array}{c}0.003^{* *} \\
(0.001)\end{array}$ & $\begin{array}{l}-0.002 \\
(0.005)\end{array}$ \\
\hline Non-wage income (in 1000s) & $\begin{array}{c}0.012 * * \\
(0.006)\end{array}$ & $\begin{array}{l}-0.023 \\
(0.027)\end{array}$ & $\begin{array}{c}0.000 \\
(0.001)\end{array}$ & $\begin{array}{l}-0.027 \\
(0.037)\end{array}$ \\
\hline Parents divorced & $\begin{array}{l}-0.089 \\
(0.055)\end{array}$ & $\begin{array}{c}-0.091 \\
(0.169)\end{array}$ & $\begin{array}{l}-0.079 \\
(0.060)\end{array}$ & $\begin{array}{l}-0.287 \\
(0.275)\end{array}$ \\
\hline Urban & $\begin{array}{c}-0.148 * * * \\
(0.051)\end{array}$ & $\begin{array}{c}-0.091 \\
(0.169)\end{array}$ & $\begin{array}{c}-0.180 * * * \\
(0.052)\end{array}$ & $\begin{array}{l}-0.331 \\
(0.228)\end{array}$ \\
\hline Child present & $\begin{array}{c}-0.266 * * * \\
(0.065)\end{array}$ & $\begin{array}{c}-0.596 * * * \\
(0.146)\end{array}$ & $\begin{array}{c}0.186^{* *} \\
(0.104)\end{array}$ & $\begin{array}{c}0.095 \\
(0.228)\end{array}$ \\
\hline Expected marriage age & $\begin{array}{c}-0.289 * * * \\
(0.030)\end{array}$ & $\begin{array}{c}-0.264 * * * \\
(0.062)\end{array}$ & $\begin{array}{c}-0.200 * * * \\
(0.029)\end{array}$ & $\begin{array}{l}-0.129 \\
(0.084)\end{array}$ \\
\hline $\begin{array}{l}\text { Number of observations } \\
\text { Number of individuals }\end{array}$ & $\begin{array}{c}28,345 \\
3,393\end{array}$ & $\begin{array}{l}5,885 \\
1,177\end{array}$ & $\begin{array}{c}33,323 \\
3,565\end{array}$ & $\begin{array}{c}4,430 \\
991\end{array}$ \\
\hline
\end{tabular}

Note: $\quad$ Standard errors are presented in parentheses. *,** and $* * *$ denote significance at the $10 \%, 5 \%$ and $1 \%$ level, respectively. 